\title{
MEMORIAS DE UN MÉDICO EN EL PROTECTORADO ESPAÑOL DE MARRUECOS A MEDIADOS DEL SIGLO XX.
}

\author{
Pere Miret Cuadras ${ }^{1}$ \\ Doctor en Medicina
}

\begin{abstract}
Resumen: En este trabajo el doctor Pere Miret Cuadras narra sus vivencias como médico rural en varias cabilas del Protectorado Español en Marruecos, casi todas en el ámbito rural. Su experiencia personal permite abordar el estado de la sanidad y la medicina entre los años 1954 y 1958 en los destinos de Beni Ahamed, el Telata de Ketama, Jemis de Anyera y Tetuán. La vocación profesional del profesional médico tenía que hacer frente a múltiples dificultades de toda índole, caso de la lucha contra enfermedades endémicas como la sífilis, el paludismo, la lepra, y otras dolencias contra las que la Administración luchaba con medios reducidos y muchas veces contra hábitos sociales y culturales que no ayudaban a la erradicación de las enfermedades.
\end{abstract}

\footnotetext{
${ }^{1}$ Pere Miret Cuadras, nació el 8 de Junio de 1928 en Sant Pere de Ribes (Barcelona). Es Doctor en Medicina por la Universidad de Barcelona. Su vinculación con Marruecos se realiza por oposición a los Servicios Sanitarios de la Zona Norte de Marruecos obteniendo su título expedido por el Alto Comisario Rafael García Valiño el día 16 de abril de 1954. Fue director del círculo médico de Telata de Beni Ahamed hasta diciembre de 1955 y del círculo médico de Ketama hasta julio de 1957. Director accidental del Servicio de Pediatría del Hospital Civil de Tetuán, y director del círculo médico del Jemis de Anyera hasta el 31 de marzo de 1958, fecha en la que causa baja voluntaria en la Administración Marroquí. Desde el año 1959 a 1961 fue médico del Hospital Militar de Barcelona, ayudante del Dr. Solsona, con el grado de Teniente médico de complemento. Posteriormente desarrolla una brillante carrera profesional como especialista por oposición libre de Pulmón y Corazón de la Seguridad Social, médico director de la Ciudad Sanatorial de Tarrasa (Barcelona) y médico director del Dispensario Central de la Lucha Antituberculosa (Barcelona). Es autor de los libros: Crònica d un metge al Marroc 1954-1958 (2006), La tuberculosi a Catalunya, des del segon terç del segle XIX a la meitat del segle XX (2011), así como de más de sesenta publicaciones en revistas nacionales y extranjeras. Ha sido miembro de los comités de profilaxis y de tratamiento deThe International Union againts Tuberculosis y presidente de la Societat Catalana de Pneumología. Es académico correspondiente de la Real Academia de Medicina de Cataluña.
} 
Palabras clave: Pere Miret Cuadras, medicina, Marruecos, Protectorado, Beni Ahamed, Ketama, Jemis de Anyera, Tetuán, organización sanitaria.

Summary: In this work, doctor Pere Miret Cuadras narrates his experiences as a rural doctor in several kabyle of the Spanish Protectorate in Morocco, almost entirely within the rural area. His personal experience allow us to understand the condition of health and medicine between the years 1954 and 1958 in the destinations of Beni Ahamed el Telata de Ketama, Jemis de Anyera and Tetuan. The professional vocation of the medical professional had to face multiple difficulties of any nature, For example; the fight against endemic diseases such as syphilis, malaria, leprosy, and many other diseases, which the administration had to deal with limited resources, and more often than not against social and cultural habits that did not help to the eradication of diseases.

Keywords: Pere Miret Cuadras, medicine, Morocco, Protectorate, Beni Ahamed, Keteama, Jemis de Anyera, Tetuán, health/sanitary organization.

"Artículo sobre la Sanidad en el Protectorado Español de Marruecos, con los conceptos que mi memoria ha podido recordar»

\section{Introducción: enfermedades endémicas en Marruecos a principios del siglo $\mathrm{XX}$}

Cuando España y Francia instauraron el Protectorado sobre el territorio marroquí, en el año 1912, el país no tenía ninguna estructura sanitaria, vivían en un aislamiento total, y la medicina científica de principios del siglo XX era completamente desconocida. Fatalistas por tradición, las enfermedades y la muerte formaban parte de la vida cotidiana, y no existía en la zona ocupada por España, ningún médico titulado en una Escuela de Medicina. Algún faquir conservaba un manual de medicina árabe de Avicena, y aplicaba alguno de sus preceptos, y el maestro-sangrador o Maalem hayyam, [1 y 2] practicaban sangrías o cauterizaciones, en especial estas últimas con resultados nefastos, y en ocasiones fatales, como tuvimos ocasión de ver [3]. La terapéutica era ancestral y muy rudimentaria, se limitaba a algunas cocciones vegetales, o a la sangre y vísceras de animales, (serpientes y cuervos) o a unos versículos, del Corán, que llevaban colgados del cuello con un canutillo (kheduil) [4], o bebían macerados en agua. 
La circuncisión, de la que no se libraba ningún varón, era ejecutada en pésimas condiciones higiénicas y con material oxidado y herrumbroso [5], que ni tan solo se lavaba. Las infecciones y hemorragias eran frecuentes y el origen de muchas complicaciones.

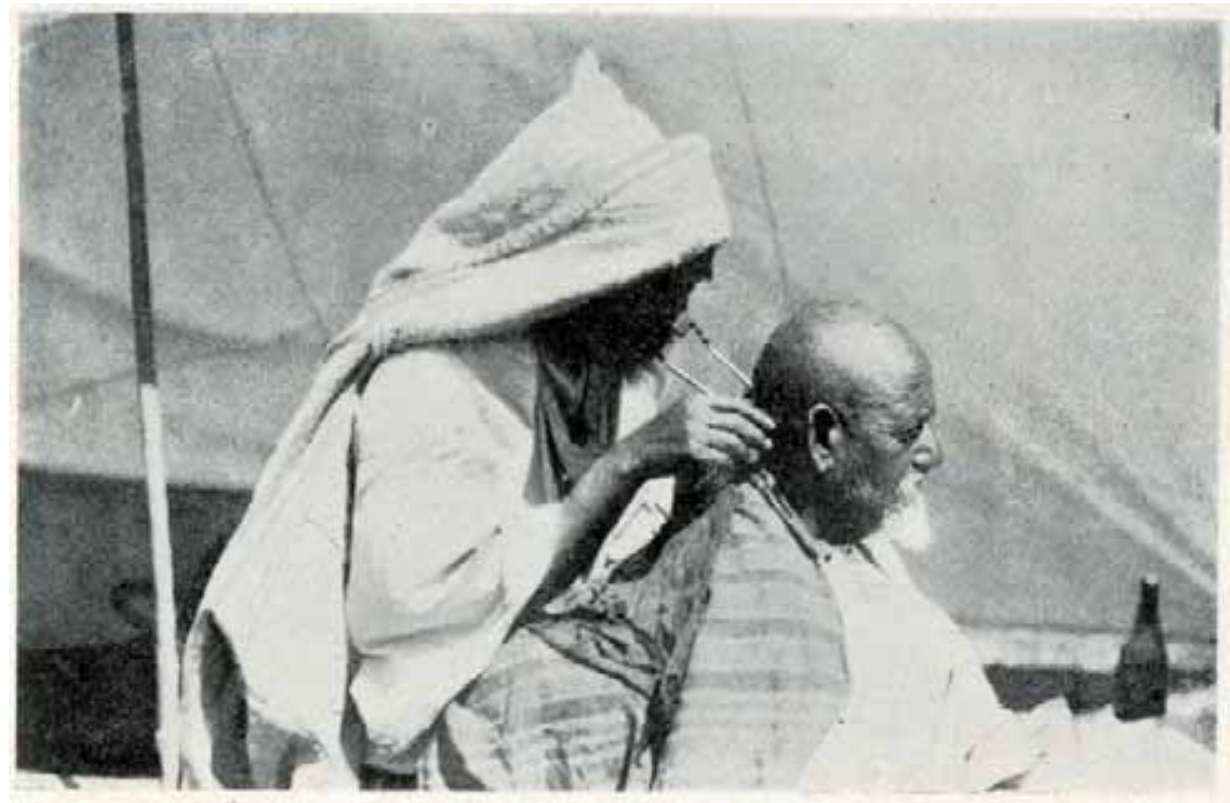

El sangrador, en su jaima del zoco, practicando una sangría.

Fig. 1. Maestro sangrador.

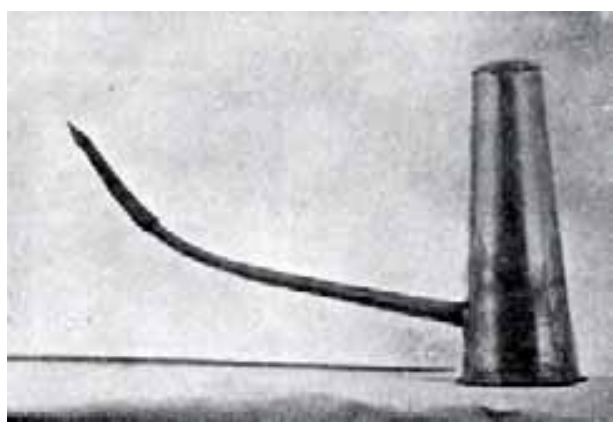

Fig. 2. Ventosa para sangría.

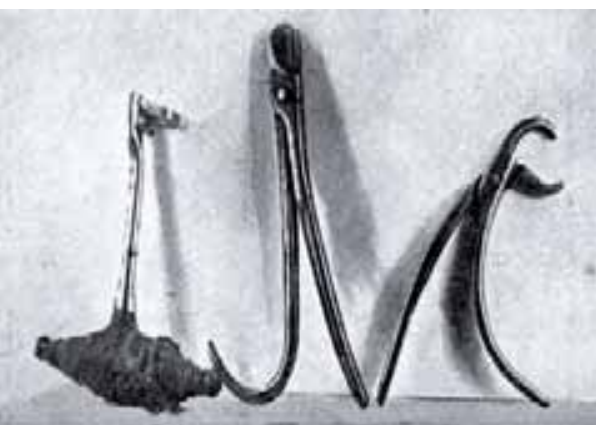

Fig. 3. Utensilios y fórceps para extracciones dentarias. 
El embarazo y el parto no estaban controlados. En general una mujer, pariente o vecina que había parido unas cuantas veces, y observado algunos partos ajenos, acompañaba a la parturienta, y si el libramiento era normal acababa bien, pero si ocurría algún contratiempo y el niño sacaba la mano, los pies, o no encajaba bien la cabeza, el desastre era seguro.

La mortalidad infantil era muy elevada, especialmente en las zonas rurales, pero imposible de conocer, al no existir registro civil. Las principales causas de muerte eran las infecciones intestinales, con diarreas, desnutrición, la malnutrición y deshidratación, pero existían otras enfermedades que contribuían a la alta mortalidad infantil.

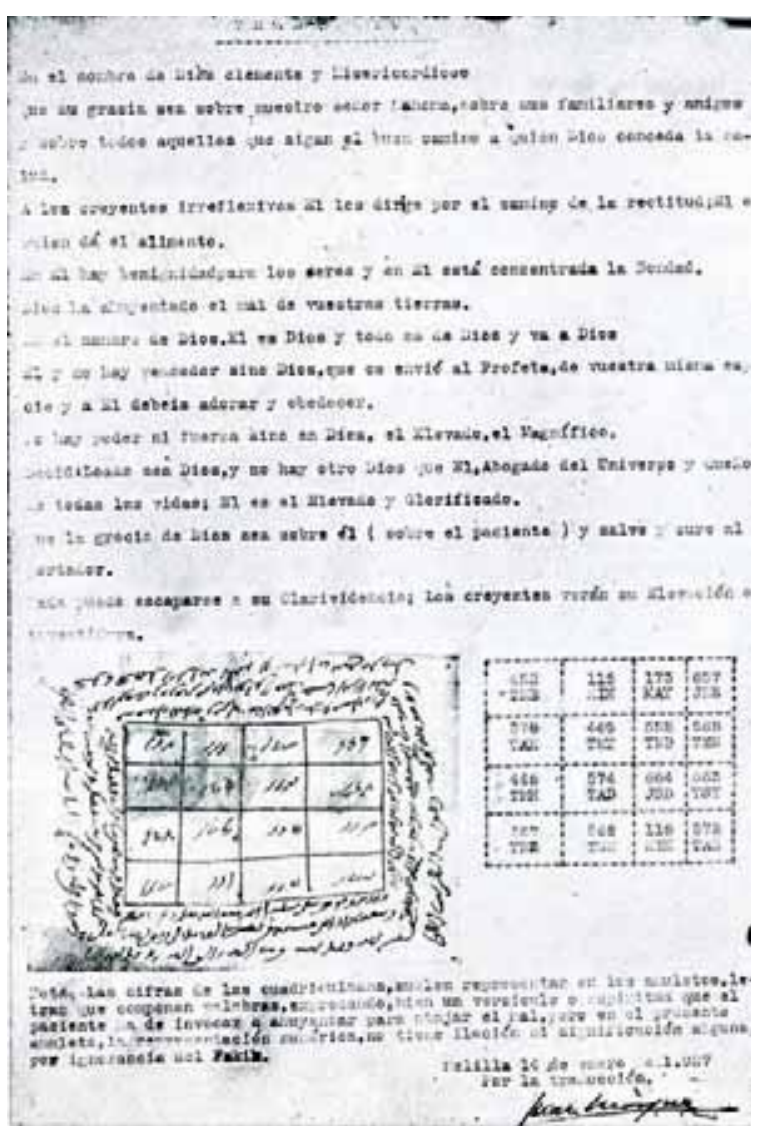

Fig. 4. Amuleto escrito y su traducción, destinado a colgarse en el cuello en un "yeduil".

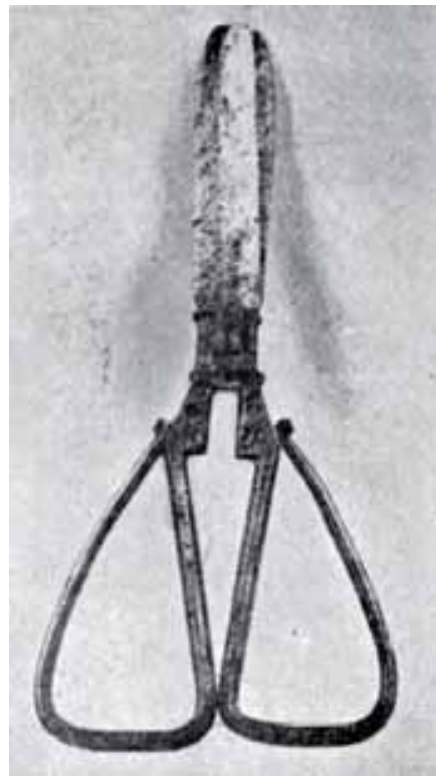

Fig. 5. Tijeras para la circuncisión. 
La sífilis o lues. Esta enfermedad era endémica y seguramente la más frecuente en Marruecos, a principios del siglo XX, y lo fue durante muchos años. En un estudio publicado el año 1939, el Dr. Solsona recoge una estadística de los cuatro años anteriores y encuentra el 54,42\% de sifilíticos entre todos los enfermos que acudieron a los consultorios médicos de Yebala. El mismo Dr. Solsona, en Alcazarquivir, entre los ingresados en el Hospital y en el Consultorio calculaba que el 79\% del total de la población, tenía lesiones visibles, las había tenido, o presentaba reacciones serológicas positivas.

Los niños se infectaban de sífilis de dos maneras. Una era la conocida transmisión transplacentaria durante el embarazo. Muchos no llegaban a término y la madre abortaba. Otros nacían con lesiones visibles, coriza con secreción muco purulenta, y posterior deformación de la nariz, pénfigo palmo plantar, grandes vesículas que se rompían dejando úlceras sangrantes, hepato esplenomegalia, etc. En otros aparecía la enfermedad a los dos o tres años. Algunos morían distróficos a los pocos meses, pero otros malvivían con lesiones oculares, de la piel, de huesos, petequias, ampollas, condilomas, defectos dentarios, incisivos en media luna llamados de Hutchinson, defectos sensoriales, sordera, queratitis, neuritis óptica, molares en forma de mora, y terminaban con alteraciones viscerales, hígado o riñón. [6, 7 y 8]

Otra forma de infectarse, menos conocida, era el contagio por la madre $\mathrm{u}$ otros adultos, con lesiones ulceradas en faringe y paladar. Al introducirle en la boca el alimento masticado, le contagiaban con la saliva, una sífilis primaria que comenzaba con un chancro en la amígdala o paladar, y seguía el curso de la sífilis del adulto. No era raro encontrar niños de dos, tres, cuatro, o cinco años con condilomas, úlceras, etc., propios de la sífilis secundaria, contagiada por vía venérea.

La tosferina y la difteria contribuían también, a la alta mortalidad infantil.

Otras dolencias eran endémicas y afectaban a toda la población. El paludismo, conocido como fiebre intermitente, era otra de las enfermedades frecuentes en el país, y a la llegada de los españoles era común entre los marroquíes. Los accesos febriles trastornaban la vida diaria de personas y familias, las remisiones y agudizaciones, la anemia secundaria, la cronificación de la enfermedad, no tratada o mal tratada, causaban invalidez y finalmente caquexia y muerte. 


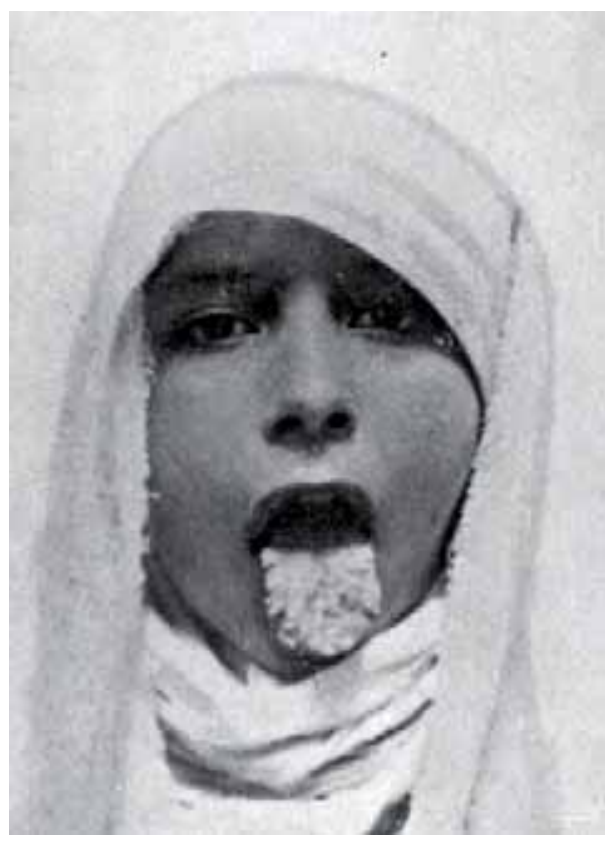

Fig. 6. Sifilis secundaria, contagiada en la infancia de lengua y boca.

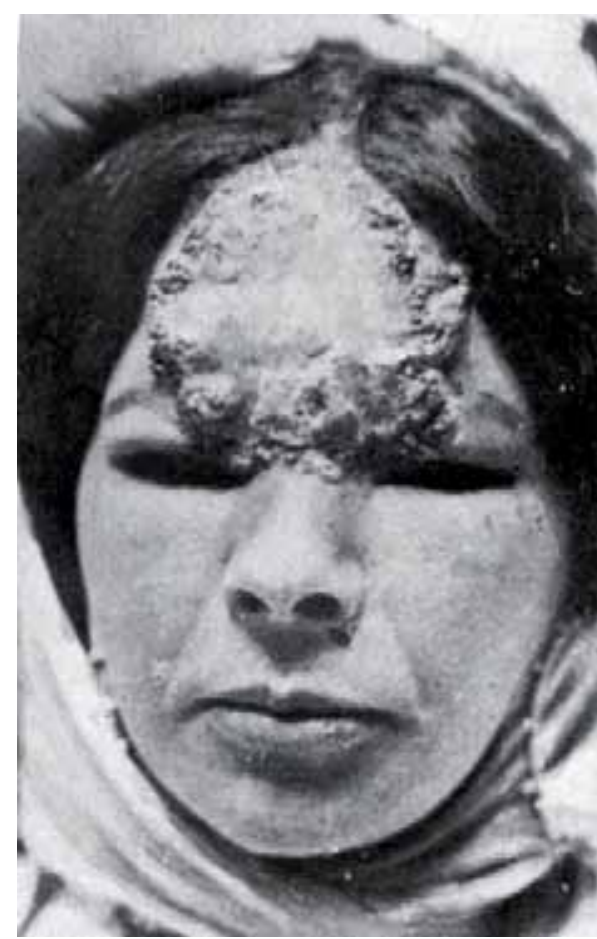

Fig. 7. Sífilis adquirida secundaria de la frente.

El marroquí desconocía la naturaleza del mal, carecía de medicamentos eficaces, e ignoraba la transmisión por el mosquito. Las viviendas de techo bajo, oscuras, mal ventiladas y de tejado vegetal, eran un vivero de estos insectos, y la permanencia al al aire libre favorecía la picadura del anofeles.

La distribución geográfica era irregular. En las zonas donde desembocan los ríos Gelú o Martín en el Mediterráneo, el Lucus en el Atlántico, la vega del río Nekor en Alhucemas, y en la desembocadura del Muluya cerca de Melilla, se formaban marismas que favorecían la reproducción del mosquito, pero el paludismo estaba extendido por todo el norte de Marruecos, ya que la escasez de agua subterránea, y la falta de pozos, en las cabilas rurales, hacia necesaria para el consumo, el agua de las charcas residuales que quedaban en verano, cuando se secaban los ríos, y que eran la única de que disponían muchos poblados para su consumo, aunque estuviera infestada de larvas de anofeles, y de otras bacterias. 
Eran comunes las infecciones de la piel, por estreptococos y estafilococos, que favorecidas por la falta de higiene, especialmente en verano, originaban impétigo, pústulas, erisipela e infecciones de las heridas y excoriaciones,

También la tiña era permanente en algunos poblados, pero como se cura habitualmente en la pubertad, no se le daba demasiada importancia. [9]

La tuberculosis era mucho más frecuente en los habitantes de la ciudad, donde vivían hacinados en pequeños habitáculos, que en el campo, donde permanecían muchas horas al aire libre.

En la zona donde desarrollé mi tarea médica durante mi estancia en Marruecos, cabila de Beni Ahamed, la mayoría caminaban descalzos. Algunos tenían babuchas, pero en general las guardaban, y se las quitaban cuando pasaban por terreno pedregoso, encharcado o en mal estado, para no estropearlas. La piel de la planta del pie, adquiría la dureza y el grosor del cuero, y soportaba la dureza y las agresiones del suelo pedregoso, pero, se resquebrajaba y aparecían fisuras profundas, muy dolorosas, y rebeldes al tratamiento.

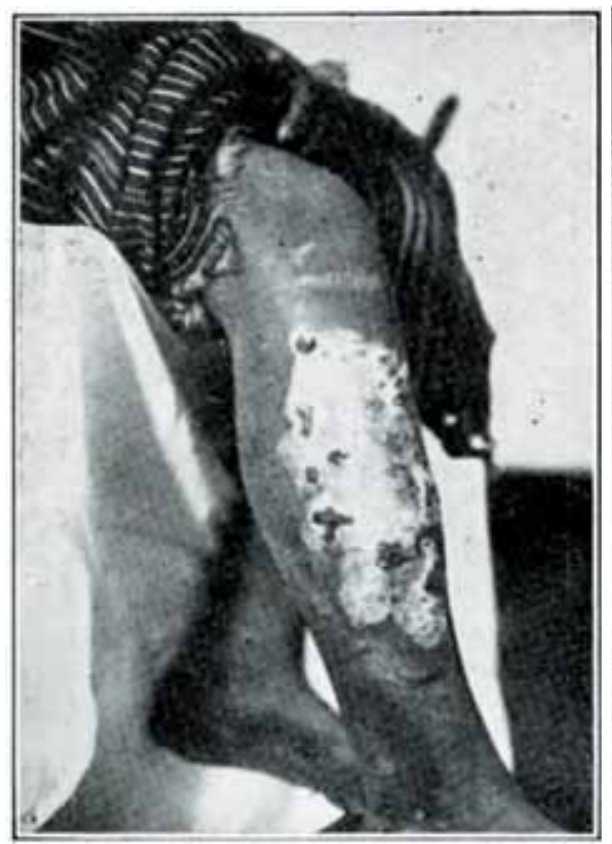

Fig, 8. Sifilis ulcerosa-costrosa de un niño de 7 años.

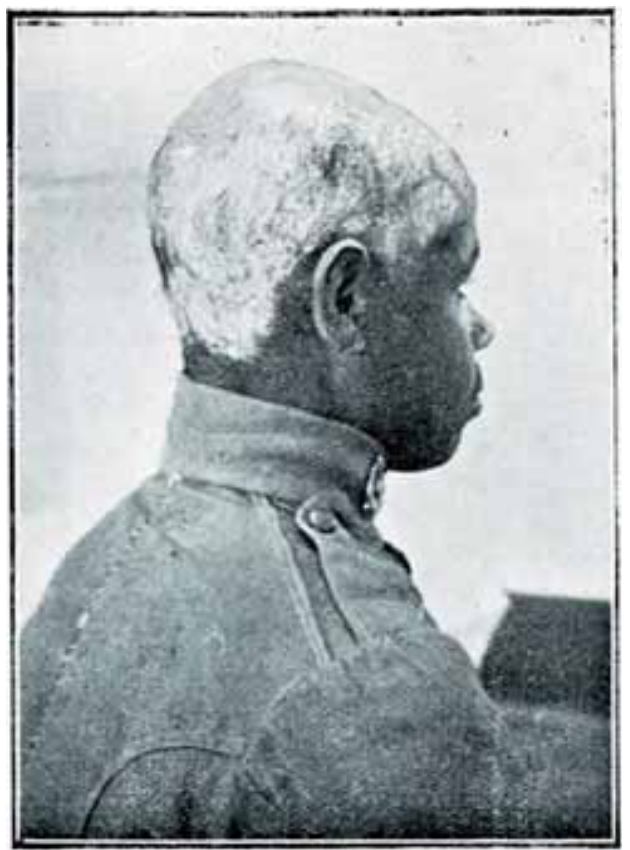

Fig. 9. Tiña favosa. 
En verano especialmente, aparecían de repente epidemias de conjuntivitis, que afectaban la casi totalidad de un poblado. Algunas eran purulentas, ulceraban la córnea y dejaban leucotomas que limitaban la visión, durante toda la vida.

Marruecos mantenía todavía, en los años treinta, epidemias de viruela, en las zonas rurales donde no se vacunaba la población.

La disentería y el tifus aparecían, siempre en relación con la contaminación del agua potable, y el Kala-Azar aparecía en ocasiones.

La alimentación era muy sobria, y no se conocían las enfermedades que aquejaban a otros países de nivel económico o cultural diferente. La hipertensión, el ictus, los infartos, la obesidad no existían, el único habitante gordo en las cabilas, era el Caid.

Existía algún caso de lepra, conviviendo con sus familiares, pero la poca capacidad de contagio y la baja concentración de la población, la mantenían estacionaria.

En estos momentos la probabilidad de que un neonato llegara a adulto era escasa. Pese a la alta natalidad, la población, no había aumentado en los últimos cincuenta años. Debemos tener en cuenta, que a primeros del siglo $\mathrm{XX}$, en España existía todavía la viruela, cien años después del descubrimiento de la vacuna, y la sífilis, el paludismo, la fiebre tifoidea, la difteria, la tuberculosis y los trastornos digestivos del lactante, mantenían una alta prevalencia y una mortalidad notable pese al salvarsán, la quinina, los sueros, los sanatorios y las nodrizas. [10]

Esta era la situación médica y sanitaria, cuando España, ocupó la zona norte de Marruecos. Desde el primer momento, se impuso proteger a sus habitantes y procurarles unas estructuras sanitarias que permitieran conocer, controlar y tratar sus enfermedades endémicas, y procurarles un sistema sanitario apropiado, para mejorar su salud.

\section{Aspectos y características de las cabilas rurales del Protectorado}

La unidad territorial era la cabila, que gobernaba un Caid y ejercía de 
juez el Cadi. Un día de la semana se dedicaba al zoco. En todas las cabilas, pero en especial las más aisladas, como la de Beni Ahamed la vida social, económica y festiva, giraba alrededor del zoco, donde se reunían todas las personas que acudían desde primeras horas, para intercambiar sus productos, encontrarse con parientes y amigos, enterarse de lo que ocurría en otros lugares, y contar lo que sucedía en el suyo, y pasar, lo que para ellos era el auténtico día de fiesta. Algunos que residían en poblados alejados veinte o más kilómetros, salían de sus casas la noche anterior, pasaban la jornada en el zoco y machaban al atardecer, para llegar de madrugada a sus hogares. [11]

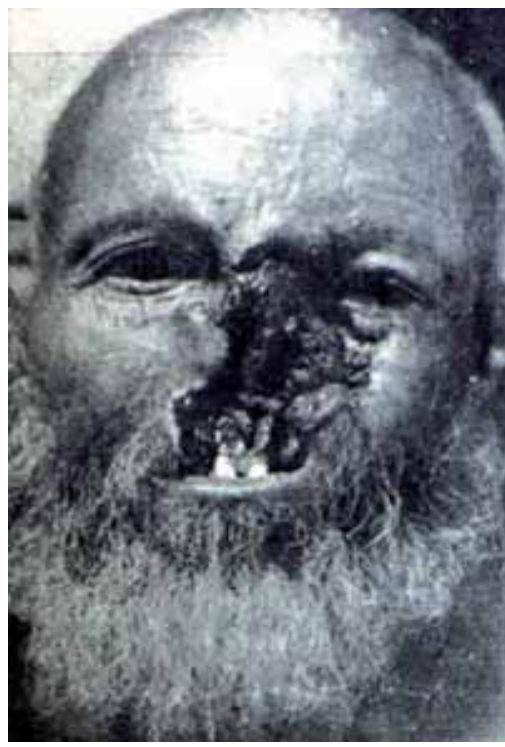

Fig. 10. Carcinoma ulcerado de la cara.

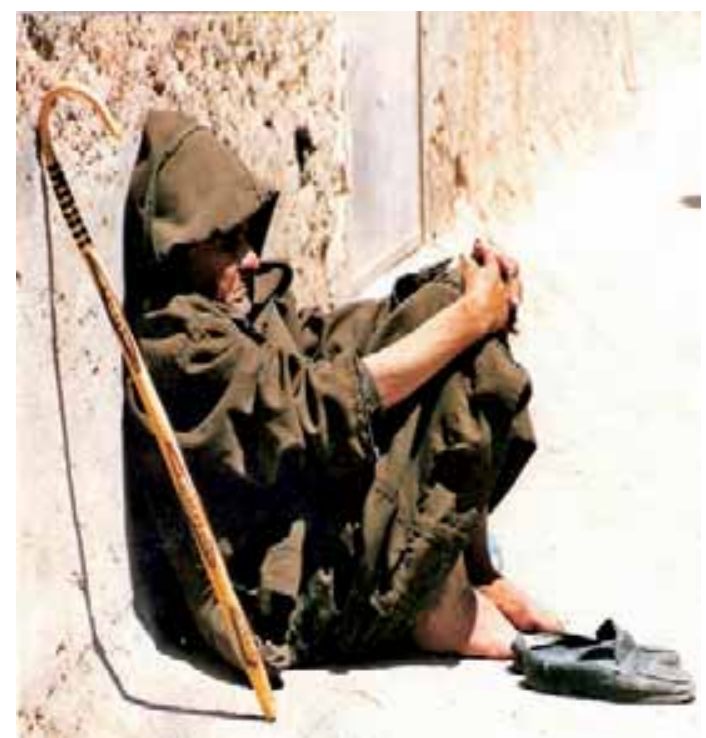

Fig. 11. Marroquí del campo.

La explanada del zoco, estaba rodeada de unas modestas construcciones de ladrillo, que se usaban como comercios y alguna de cafetín. En ellas, podían adquirirse algunas piezas confeccionadas, muy simples, te, azúcar, patatas, babuchas para los pocos ricos, baratijas, y algunos cacharros de barro cocido o de latón; en el cafetín se discutía y se servía té verde, pero el verdadero comercio estaba al aire libre; millares de personas, la práctica totalidad de los habitantes de la cabila, procuraban intercambiar o vender los productos de su cosecha; unas gallinas del tamaño de una perdiz, que corrían entre las casas de los pobla- 
dos, unos huevos del tamaño de los de paloma, tomates, limones, y algunos, un cabrito.

El calor, el contacto continuo con cuerpos sudados, la gritería constante, el polvo, la multitud apretujada que te empujaba y golpeaba constantemente, los asnos y mulos que circulaban, entre el personal, sin respeto, y te apartaban, a empellones con sus posaderas, o te pisaban con sus cascos herrados, los encantadores de serpientes, el cadi aplicando la justicia en una esquina, el condenado a contar a gritos el castigo que se le había impuesto por sus fechorías, te trasladaban a un mundo anterior.

Las cabilas de la costa Atlántica, las del Mediterráneo, próximas aTetuán, y las cercanas a Melilla, son distintas, más ricas, con más lluvia, y de un terreno más favorable para el cultivo. En estas, los zocos están provistos de verduras, frutas, legumbres y cereales de su propia huerta, y de pescado que proporcionan sus barcos. Las gallinas, cabras, ovejas y vacas tienen el tamaño propio de estas especies, y la producción de leche y derivados era la que correspondía a su clase.

Las cabilas y dentro de ellas los poblados, estaban unidas por caminos terreros mejor o peor acondicionados, según fuera el territorio más llano en las zonas costeras deYebala, el Lucus y el Kert, o montañoso desde Beni Aros a Beni Buyahi.

En estas cabilas del centro, el terreno es seco pizarroso, montañoso, quebrado, los caminos inestables, inseguros, la lluvia escasa; durante los meses secos, solo queda alguna charca, en el cauce de los ríos, donde se aprovisionan de agua las mujeres, abrevan los animales, se desarrollan las larvas y pululan todo tipo de bacterias. No existían ni vehículos a motor, y ni tan solo carretas de tracción animal, de dos ruedas. Crecían tan solo matorrales de hoja dura y espinosa y algún olivo o una higuera en una hondonada protegida de la erosión, que conservaba mejor la humedad. No se cultivaba ningún tipo de verduras, ni de cereales, tan solo la avena se plantaba en pequeños bancales, y se recogía (mulana araf) si las circunstancias habían sido favorables.

El musulmán de la cabila era tan pobre como el terreno, poseía una chilaba vieja que servía también de manta, a veces heredada de su padre, un 
camisón, unos zaragüelles, y el tarbús. Dormía sobre una especie de diván duro, que construía, arrimado a la pared, con el mismo ladrillo de barro secado al sol, usado para construir su casa, y que recubría con pieles de cabra. Unos, platos y bandejas de barro cocido, latas viejas oxidadas, y la tetera de latón con sus vasos amarillentos por el uso, completaban el ajuar.

\section{Primeras actividades médicas}

Las primeras atenciones que recibieron los enfermos marroquíes fueron las realizadas por los médicos militares de las tropas españolas, que viendo la falta de atención médica que tenían aquellas gentes, decidieron tratar en los zocos de las cabilas ocupadas, a los musulmanes que lo solicitaban. [12]

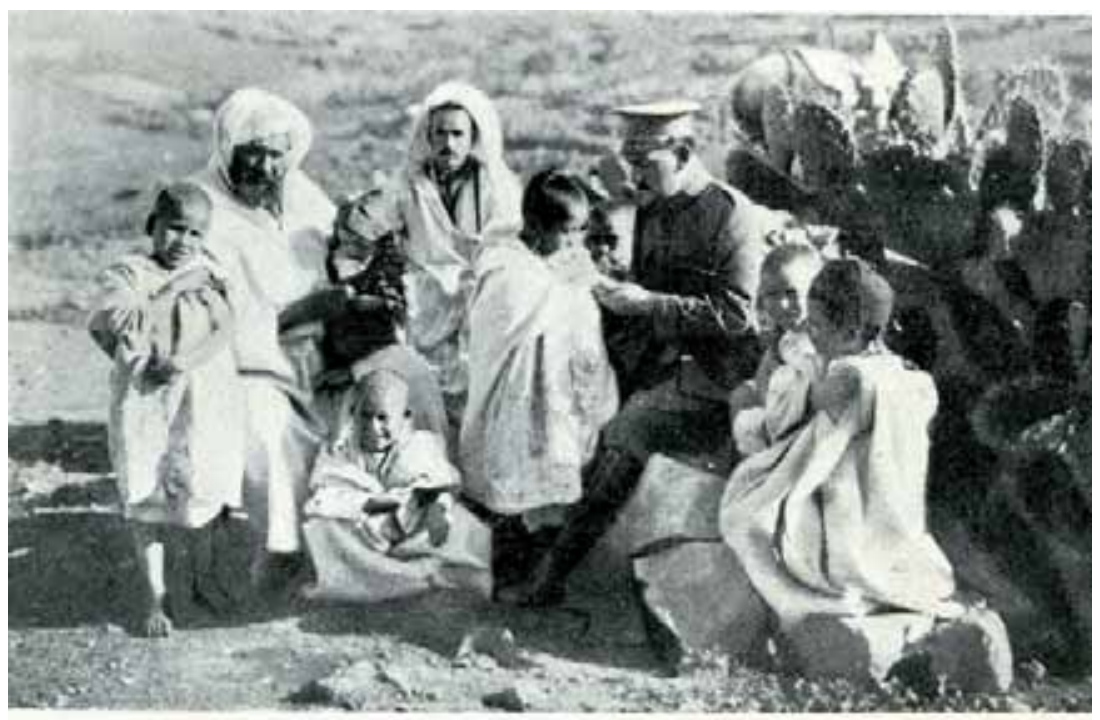

Labor de vacunación de los medicos militares ca los primeros tiempos de nuestra accion en Marruccos.

Fig. 12. Vacunación a cargo de los médicos militares.

Poco a poco y visto el éxito y los buenos resultados de estas consultas, se habilitaron, en tiendas de campaña, pequeños puestos fijos, atendidos por médicos del ejército, que examinaban y facilitaban la medicación gratuita, a todos los indígenas, amigos o enemigos, que acudían a la consulta. 
Posteriormente, en las cabilas pacificadas, se ubicaron, cercanas a los zocos, las Intervenciones, el organismo que controlaba la vida general de las cabilas, con un Interventor, como asesor del Caid, que era un capitán del ejército, un ayudante, un administrador, y un par de escribientes, con la misión de organizar administrativamente la cabila, mantener el orden y aplicar la justicia. Allí se instaló un médico militar, que se dedicó exclusivamente a la atención de la población civil. Así nacieron los primeros médicos de la sanidad en Marruecos, los Médicos de las Intervenciones. [13]

El año 1918 a medida que se pacificaba el Protectorado, se creó el Servicio Sanitario Oficial que programó, en las principales ciudades, la construcción de hospitales para los marroquíes, que serían atendidos por médicos civiles españoles, y las llamadas Juntas de Servicios Municipales, para los enfermos ambulatorios.

En el campo marroquí la asistencia médica continuaba a cargo de los médicos militares de las Intervenciones, establecidos permanentemente junto a zocos importantes. La misión de estos médicos era doble, atendían en la consulta a los enfermos, en general con enfermedades que llevaban años mortificándolos, como la sífilis, y el paludismo. Los enfermos, como un milagro, veían desaparecer sus repugnantes lesiones mucosas y dérmicas [14] después de unas inyecciones intravenosas de salvarsán, o la invalidante fiebre intermitente después de un tratamiento con quinina. También eran frecuentes las fracturas de extremidades y las heridas accidentales o por agresión, que acudían cada vez en mayor número, al comprobar que la sutura y el vendaje de yeso, que desconocían, proporcionaban unos resultados que les dejaban maravillados.

Otra misión necesaria, la realizaban recorriendo a caballo los poblados, vacunando contra la viruela, difteria, repartiendo medicamentos antipalúdicos, antisépticos, antihelmínticos, y adoptando medidas profilácticas contra el anofeles y las larvas. 


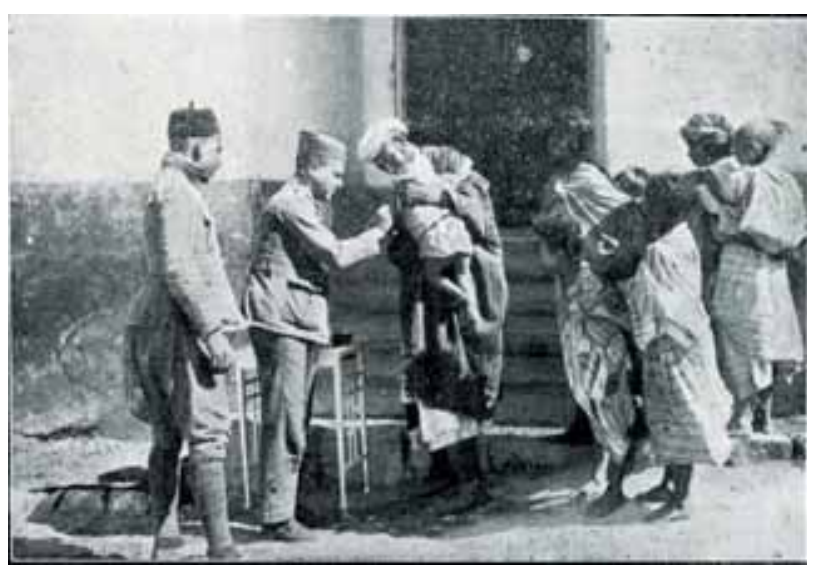

Fig. 13. Asistencia sanitaria de médicos militares.

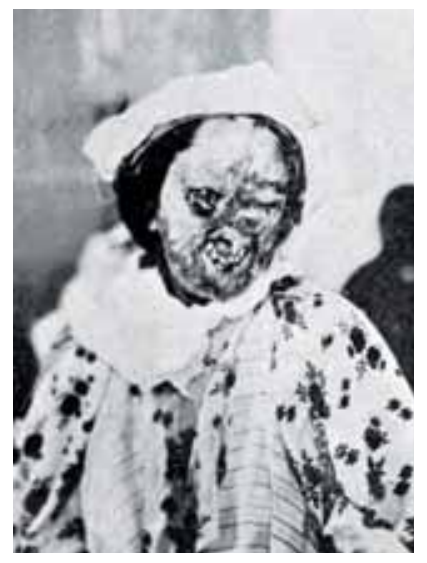

Fig. 14. Sífilis en la cara en fase de cicatrizar.

Rasgos de la organización administrativa y características de las zonas rurales

En el año 1927, pacificado el Protectorado, para coordinar la política colonial se creó la Dirección General de Marruecos y Colonias. El Jalifa, Hassan ben el Mehdi, presidió el gobierno propio del país llamado el Makhzen, en representación del Sultán. El Alto comisario, era la autoridad suprema del protectorado, que ordenaba y resolvía las cuestiones de todo tipo que se presentaban.

Se organizó administradamente esta Zona Norte, en cinco regiones, que se llamaron Intervenciones Territoriales:Yebala, Lucus, Gomara, El Rif y Kert. Les capitales eran Tetuán, Larache, Chauen, Villa Sanjurjo y Nador. Cada una de estas regiones estaba dividida en cabilas. Algunas como Guesaua, Tagsut o Mestasa, las mas pequeñas, tenían alrededor de $100 \mathrm{~km} 2$; la mayor parte, como Tlata de Beni Ahamed, Beni Arós, o Ketama, tenían entre 400 y $500 \mathrm{~km} 2$, y las más extensas como Beni Urriaguel y Beni Buyahi sobrepasaban los1.000. La media de población en las cabilas, era de unos veinte mil habitantes, repartidos en pequeños poblados que tenían entre treinta y cincuenta habitantes la mayoría de ellos, no pasando los mayores de ciento cincuenta. En cada una de las cabilas residía un Interventor Comarcal, que era el representante del Interventor Territorial, y este lo era del Alto Comisario. 
Se mejoraron las comunicaciones, poco a poco. Unas carreteras aceptables unieron entre si las principales ciudades de las provincias de Yebala y el Lucus: Tetuán, Ceuta, Tánger, Arcila, Larache y Alcazarquivir. Se inició la construcción de una carretera, de cuatrocientos cincuenta kilómetros para comunicar Ceuta y Melilla, con ramales a los distintos zocos. Estos caminos rurales, más o menos largos, si estaban en terreno llano eran normalmente transitables para vehículos de motor, pero en las cabilas fronteras con el protectorado francés, el terreno es montañoso y accidentado, y algunas de estas vías, que tienen hasta treinta y más kilómetros, en zonas montañosas y en época de lluvias, eran con frecuencia intransitables. El recubrimiento con asfalto se efectuaba por tramos, y cuando Marruecos consiguió la independencia, quedaban todavía, kilómetros de carretera sin recubrir.

Durante mucho tiempo, el único transporte público que tuvieron los habitantes de las cabilas, un día a la semana, fueron los autobuses de la compañía la Valenciana, el día de zoco, y al no existir en árabe la palabra autobús, adoptaron el nombre "an valenciana” como su equivalente. Las personas se desplazaban a pié, pocos en mulo, el asno era usado, en general, para la carga.

La visión que presentamos de estas comarcas rurales aisladas no es aplicable a la totalidad del país. En Tetuán, se erigieron centros sanitarios y de especialidades, y poco a poco, en las ciudades de Larache, Nador, y finalmente Villa Sanjurjo, se construyeron hospitales, con servicios quirúrgicos y algunas especialidades. [15]

En el resto del territorio, en todas las cabilas, se construyó un Centro Médico, con un único facultativo, que aislado, con recursos limitados y al cuidado de una población que le sobrepasaba, se esforzó para socorrerla y ayudarla, y con voluntad y dedicación consiguió reducir las enfermedades endémicas y las infecciones y trastornos nutritivos de la infancia, causantes de la elevada mortalidad infantil, prevenir enfermedades epidémicas coma la viruela y la difteria, e introducir una medicina científica, en un pueblo, que conservaba unos conceptos médicos del siglo VIII

Esta somera descripción puede contribuir a comprender mejor, las dificultades que encontraron los médicos, en especial los rurales, para desarrollar su labor. 


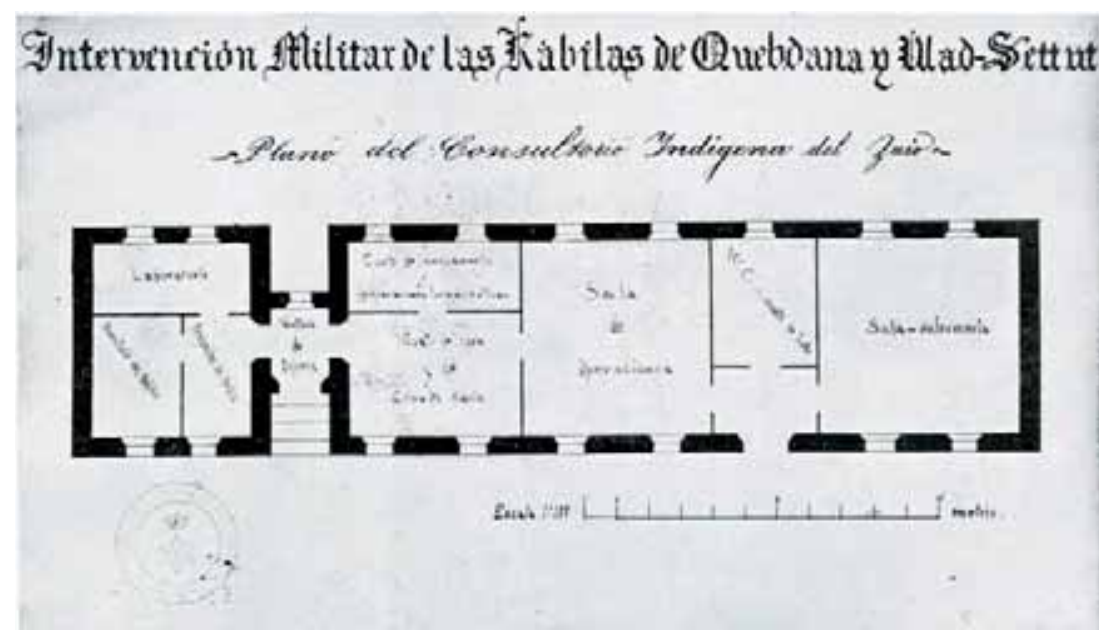

Fig. 15. Intervención militar de las cabilas de Quebdana y Ulad Settut, Consultorio indígena del Zaio.

\section{La organización sanitaria del Protectorado}

Derrotado Abd el-Krim y organizada administrativamente la zona, los Servicios Sanitarios Públicos pudieron, poco a poco, mejorar y completar una asistencia médica más estable y más completa. En el año 1929 se creó el Órgano Central Director de la Sanidad e Higiene Públicas en la Zona, que dependía directamente de la Delegación de Asuntos Indígenas, y de manera progresiva los médicos militares fueron substituidos por médicos civiles.

En Tetuán, la capital desde 1913, la Inspección de Sanidad, había autorizado en el año 1929 a la doctora María del Monte López Linares, a poner en marcha un Dispensario para mujeres y niños musulmanes. La doctora María del Monte fue una mujer extraordinaria, había recalado en Marruecos por su cuenta, ayudada en principio, por la periodista Josefina Carabias, y posteriormente, en su tarea sanitaria, por una ayudante musulmana, Rahma ben Alí, que ella misma educó y enseñó. Más tarde se incorporó la doctora Nieves González Barrio, una colaboradora del Dr. Pittaluga. Consiguieron inaugurar en Tetuán una Escuela de Practicantes y Enfermeras Indígenas y una Escuela Oficial de Puericultura. Ellas comenzaron la campaña antivariólica, vacunando a millares de personas. [16] 


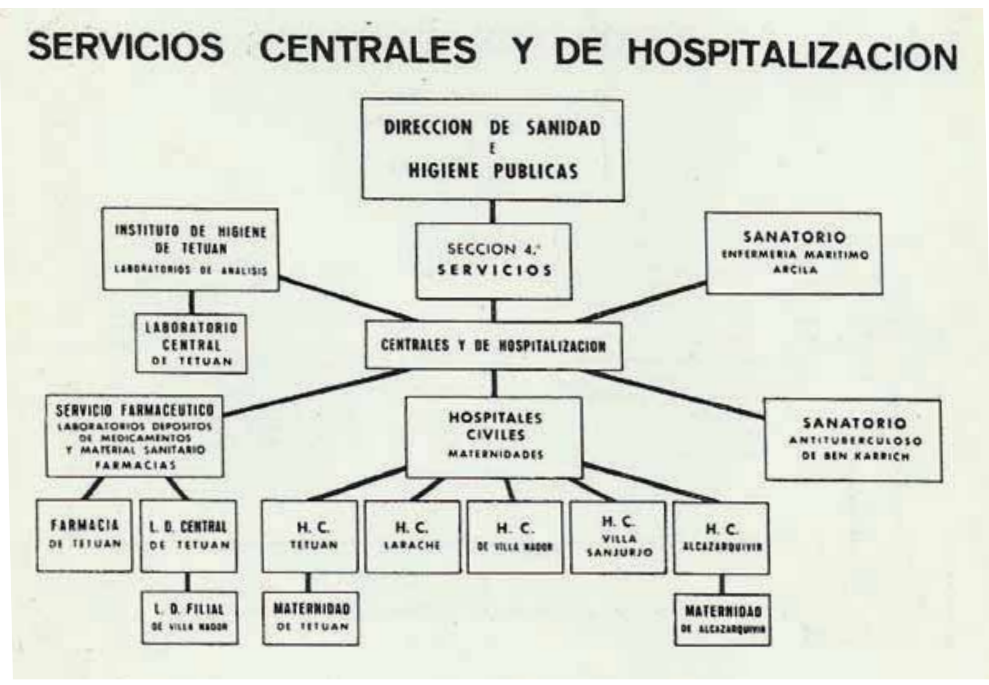

Fig. 16. Servicios Centrales y de Hospitalización.

También instauraron un Consultorio de mujeres y niños musulmanes en Chauen, con la intención de extender este servicio a otras ciudades, pero fue el único.

La doctora del Monte dedicó su vida profesional a Marruecos, consiguiendo apoyo y ayuda de la Alta Comisaría y de las autoridades sanitarias, para llevar a buen fin sus proyectos, que prestaron gran ayuda a la población. Al finalizar el Protectorado, figuraba con el número cuatro en el escalafón de Médicos de los Servicios Sanitarios.

En el año 1935 en el Primer Congreso Nacional de Sanidad, en Madrid, se dedico una ponencia a la "Necesidad de incorporar a la Sanidad Nacional, los Servicios Sanitarios de la Zona del Protectorado”.

Fue en el año 1939, cuando se puso en práctica la Organización de la Sanidad Oficial del Protectorado, como un servicio exclusivamente estatal que comprendía todas las actividades médicas y sanitarias, locales, regionales y nacionales.

El proyecto, se confió al Dr. Juan Solsona Cunillera, que era, en aquellos momentos Director de Sanidad de la Zona. El fue quien organizó la sanidad en el norte de Marruecos, el creador, el impulsor y el ejecutor del pro- 
yecto, que se desarrolló con una notable eficacia del método y que se mantuvo hasta el final del Protectorado. Ha sido el médico que más trabajó, para conseguir una sanidad práctica y beneficiosa en todo el Protectorado.

Merece una breve biografía. Nacido en Albi (Tarragona) el año 1907, marchó siendo teniente médico a Marruecos, en el año 1931, destinado a la cabila de Melusa frontera con Tánger, para atender exclusivamente a la población musulmana. En el año 1933 aparecieron unos casos de peste bubónica en Tánger, y él con sus propios medios, levantó un cordón sanitario que impidió la entrada de la peste en el Protectorado. Fue condecorado por la República, con la Orden Civil de África. [17]

\section{SERVICIOS LOCALES}

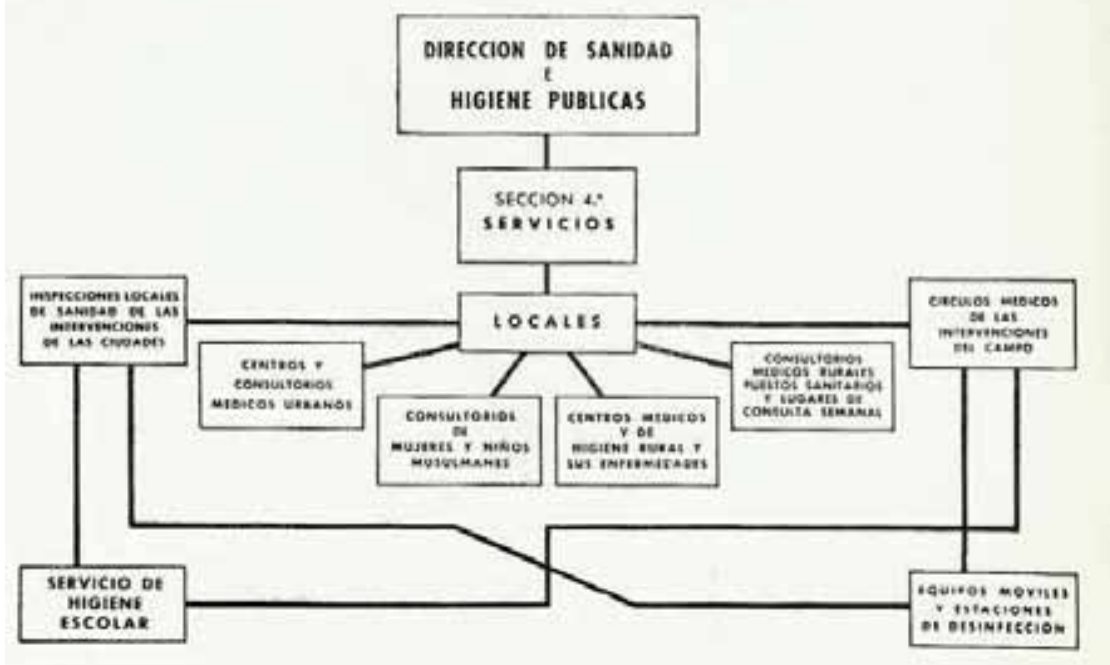

Fig. 17. Servicios Locales.

Pasó a la Dirección del Hospital Civil de Alcazarquivir, y en el año 1938, a los treinta y un años, fue nombrado Director General de Sanidad del Protectorado. Era un hombre inteligente, capacitado para el mando, muy trabajador, ordenado, voluntarioso, exigente consigo mismo, y muy exigente para los demás, apartaba inmediatamente de su lado a los que no seguían su ritmo, a los que se acomodaban a un horario, y a los que consideraban el trabajo, una obligación. Siempre educado, íntegro, obsesionado por el des- 
pilfarro del dinero público, nunca perdía el autocontrol, y a pesar de su corta estatura, su mirada firme y autoritaria, se imponía, y sus decisiones correctas eran la que prevalecían.

Propuso los siguientes objetivos:

Unidad en la acción médica y sanitaria, lo mismo en la actividad diaria, que en los casos especiales y de urgencia. Esta unidad en la Organización tenia en Marruecos especial significación, por cuanto allí la Sanidad no podía considerarse tan solo en el aspecto técnico y social, sino que alcanzaba un gran valor como misión de Protectorado.

Perfección en los Servicios, para que cada uno estuviera bien montado y dotado de personal y material adecuado.

Economía general en el presupuesto, para evitar la duplicidad de servicios.

Ordenación lógica y justa del personal facultativo y auxiliar, evitando las tendencias localistas, siempre propicias a mirar más los intereses personales, que la bondad de los servicios.

Competencia y calidad de los facultativos y técnicos sanitarios, con una cuidadosa selección de los que mediante las pruebas oportunas, pretendan entrar a formar parte de los cuerpos estatales.

El Majzen se encargaría de todos los servicios médicos y sanitarios oficiales, reorganizando los que pertenecían a las Administraciones locales, y conjuntándolos con los ya establecidos.

El presupuesto de Sanidad e Higiene Pública del Majzen Central, que cubre los servicios expresados, se nutría de dos aportaciones:

De las Corporaciones locales, el 10 por 100 de sus respectivos presupuestos anuales de gastos, y en segundo lugar, de Acción Benéfico Social dependiente de la Dirección de Beneficencia y Obras Sociales de la Delegación de Asuntos Indígenas, como contribución a los servicios que se prestan a las personas económicamente débiles. 
Esta organización fue muy útil y persistió hasta el final del Protectorado. Su cabeza era la Dirección de Sanidad e Higiene Pública, o Inspección de Sanidad, órgano de dirección técnica e inspección médico-sanitaria, que dependía directamente de la Delegación de Asuntos Indígenas, de la Alta Comisaría.

Comprendía diez secciones: Higiene, Epidemiología, Estadística, Servicios (con dos subsecciones, una para los centrales y hospitales y otra para los locales), Luchas y campañas sanitarias, Profesiones sanitarias, Personal, Asesoría farmacéutica, Sanidad marítima y Asuntos generales. [18]

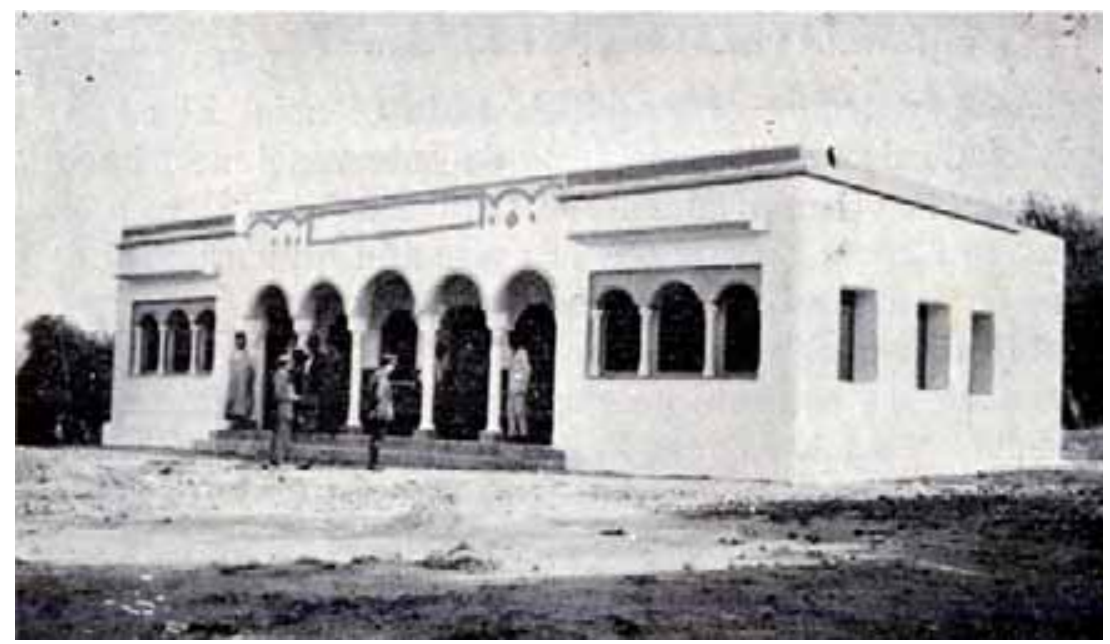

Fig. 18. Consultorio de Beni Gorfet.

Las secciones de Servicios y Luchas merecen un examen pormenorizado. Los Servicios de la Dirección de Sanidad eran los que realizaban el trabajo médico cerca de la población. Constaba de Servicios Centrales y de Hospitalización y Servicios Locales.

Los Servicios Centrales abarcaban todo el Protectorado y estaban formados por: El Instituto de Higiene de Tetuán, dotado para el estudio de problemas higiénicos, epidemiológicos y sanitarios, y de él dependían los laboratorios de análisis dedicados a la práctica clínica, y el Servicio Farmacéutico que abastecía de medicamentos, vacunas, material sanitario y de laboratorio, todos los centros sanitarios, tanto hospitales como centros rurales. Todos los medicamentos y materiales eran gratuitos para los marroquíes. Existían dos depósitos; uno en Tetuán y otro en Nador. 
Pasados unos años, cuando se habían podido desarrollar una buena parte de los proyectos programados en un principio, los servicios de hospitalización comprendían:

Los Hospitales Civiles de Tetuán, Larache, Alcazarquivir, Nador y Villa Sanjurjo, el último edificado, con una capacidad total de 710 camas. Anejos a los hospitales funcionaban pabellones de Servicios de Maternidad. En el Hospital Civil de Tetuán se construyó un Pabellón para la Clínica de Pediatría, Puericultura y Centro de Alimentación.

El Sanatorio Antituberculoso de Ben Karrich, a 10 Km. de Tetuán, con 152 camas, o el Sanatorio Marítimo de Arcila.

En las ciudades existían Centros Médicos, urbanos, con servicios de medicina y cirugía general y algunas especialidades como la odontología y oftalmología. En Tetuán, Larache y Alcazarquivir, se instauraron Consultorios de mujeres y niños musulmanes, atendidos por personal médico y auxiliar femenino

En Chauen y en Targuist, dos poblaciones con un número importante de habitantes, se construyeron Centros Médicos y de Higiene Rural, un poco mayores que los rurales, con un solo médico, pero con más personal auxiliar, mejor dotados y que disponían de un aparato de Rayos X.

Las zonas rurales, ocupaban el 90 por ciento del territorio marroquí, y en ellas residía el 75 \% de la población. En las Intervenciones, que así se llamaron las cabilas ocupadas, se instalaron Consultorios Médicos, que eran las Inspecciones locales de sanidad en el campo. Instalados siempre cerca de los zocos, tenían a su cargo la asistencia médica de la población de una cabila, que se denominó Círculo Médico. El médico residía en una modesta vivienda anexa al Consultorio Médico Rural. Tenía como ayudantes, en los primeros tiempos a un Practicante español, poco después marroquí, formado en la Escuela de Sanitarios marroquíes que se inauguró en Tetuán, y una auxiliar, una mujer sin ningún estudio, pero que hablaba español. El Consultorio disponía de sala de espera, despacho médico, sala de curas, laboratorio y enfermería, normalmente con tres camas.

En núcleos de población alejados y en alguna cabila grande, donde el 
Consultorio quedaba lejos, se instalaron Puestos Sanitarios atendidos por un Practicante, que recibía la visita semanal del médico del Círculo. Poco a poco se construyeron Consultorios en todos los zocos importantes, llegando el número de Círculos Médicos a 41. El total de Puestos Sanitarios era de 26. [19]

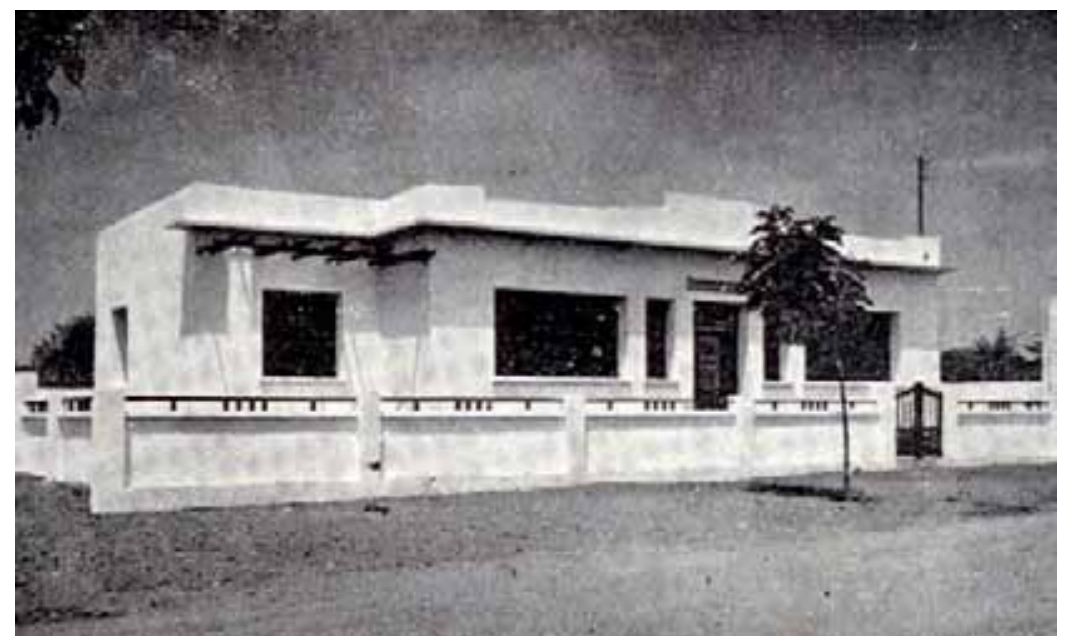

Fig. 19. Consultorio de Barrio Nuevo en Larache.

La labor del médico rural tenía, como en los primeros tiempos, dos vertientes, asistencial la primera, diagnosticando y tratando en el Consultorio a los enfermos, suturando heridas, enyesando fracturas, entregando medicamentos, insistiendo en la manera de tomarlos, tomando muestras, para su examen en el laboratorio, etc., y asistiendo en su domicilio, a los enfermos que lo solicitaban, que eran muy pocos.

La segunda, era una función sanitaria, vacunando, luchando contra el anofeles y sus larvas, aconsejando el uso de agua potable y la manera de obtenerla, si era posible.

Las Inspecciones locales de sanidad y los Círculos Médicos poseían equipos de desinfección. En los Círculos Rurales consistían en dos sulfatadoras de mochila, que pulverizaban el insecticida sobre las paredes y techos, y unos barriles de petróleo para eliminar las larvas de anofeles en las charcas.

Un caballo retirado del ejército, era el compañero inseparable e indispensable del médico rural. 
La Dirección de Sanidad de la Zona, era consciente de que los Consultorios rurales, eran fundamentales para el control de las enfermedades endémicas en territorio marroquí, y para inculcar unas mínimas medidas higiénicas, a la población que más las necesitaba. También conocía cuales eran las dificultades para su buen funcionamiento; un médico no puede atender correctamente, a veinte mil personas, dispersas en una extensión de $500 \mathrm{Km} 2$, residiendo en pequeños poblados, algunos alejados veinte o más Km. del Centro, y unidos por caminos de herradura. [20] El médico, aislado, con un trabajo complejo, duro, y sin horario, estaba obligado a resolver todo tipo de situaciones comprometidas, que podían sobrepasar su capacidad, y las posibilidades del Centro.

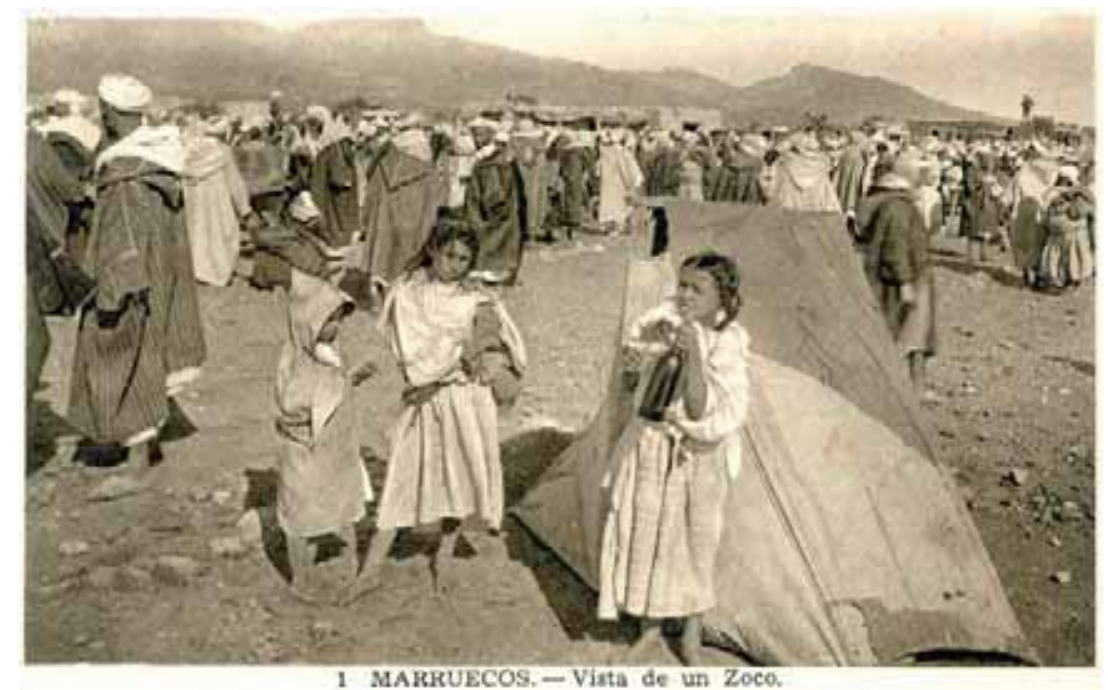

Fig. 20.Vista de un zoco.

La sección quinta de la Dirección de Sanidad dirigía las Luchas y Campañas Sanitarias. Su desarrollo corría a cargo de los Inspectores Locales de Sanidad en las ciudades, y del médico de las Intervenciones en el campo. Las Luchas Sanitarias eran permanentes y las Campañas eran periódicas o accidentales. Estas iban precedidas, en las ciudades, de propaganda divulgadora en árabe y español, por medio de charlas, artículos, carteles y notas en la prensa, que pretendían enseñar y convencer al marroquí. Puntualmente, se repartían carteles llamativos para recordar las luchas antipalúdica, antituberculosa, de higiene infantil y de higiene en general. [21] 
Se puso en marcha la lucha antipalúdica. El Servicio de Obras Públicas colaboró eficazmente, sanando grandes extensiones de terreno lacustre, próximas a importantes núcleos de población, que eran grandes viveros de mosquito anofeles. Se sanearon más de 8.000 hectáreas del valle inferior del río Martín, la laguna Guedira, próxima a Larache, los terrenos pantanosos próximos a Arcila, y otros cerca de Alcazarquivir.

Todos los Consultorios, en ciudades y rurales, estaban obligados a llevar un registro de los enfermos diagnosticados por primera vez, y de los casos recidivantes, y a controlar el tratamiento hasta completarlo en su totalidad.

El tracoma predominaba en la región oriental, aunque en mayor o menor proporción existían casos en toda la Zona. La lucha antitracomatosa instaló consultorios en Tetuán, Larache, y Nador, con un equipo de oftalmología móvil.

Se organizó la Lucha Antivenérea y se establecieron Clínicas Especiales o Sifilicomios en las cinco ciudades cabeza de provincia, y como la sífilis endémica, era la enfermedad que más afectaba a la población, también en los Círculos Rurales, se prestaba una especial atención y un especial control a los enfermos sifilíticos.

La eficacia y la espectacularidad del Neosalvarsán, facilitaron el cumplimiento de los tratamientos, y contribuyeron a prestigiar al médico y a la medicina foránea.

El Servicio de Profilaxis Social antivenéreo, controlaba, trataba y retiraba del servicio, teóricamente, a las prostitutas afectadas, hasta su curación.

La lúes no era la única enfermedad venérea. En los centros rurales, donde se las obligaba a pasar un examen semanal bacteriológico de secreciones recogidas en el hocico de tenca, estaban también infectadas y reinfectadas por el gonococo, resistente a los medicamentos. Después del otoño de 1955, en el que se suministró penicilina en solución oleosa, rápidamente adquirieron resistencia a este antibiótico.

La Lucha Antituberculosa requirió una legislación especial. Se creó el Patronato Nacional Antituberculoso, y se pusieron en marcha unas Consultas Especiales de Tuberculosis en las ciudades, donde se concentraban la mayoría 
de enfermos. Para los bacilíferos, y los que requerían hospitalización, se construyó un Sanatorio en Ben Karrich, con 120 camas. [22]

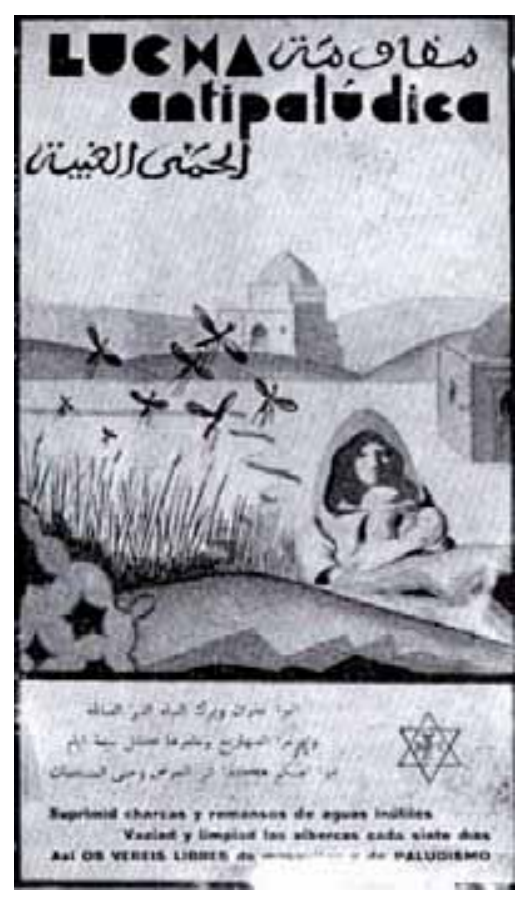

Fig. 21. Cartel de Lucha Antipalúdica..

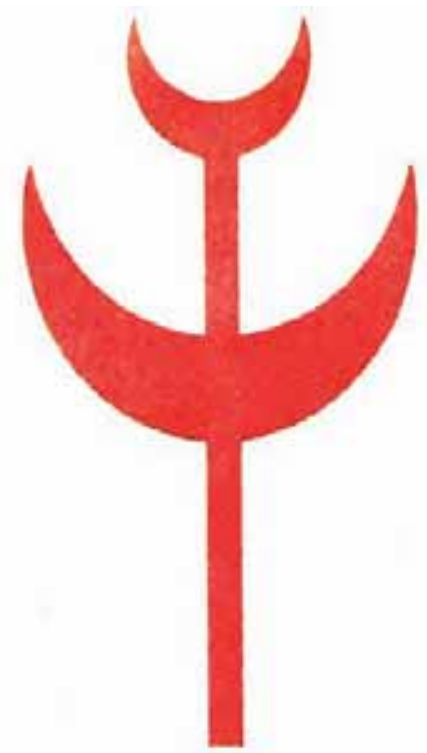

Fig. 22. Emblema de la Lucha Antituberculosa.

Contra la lepra, se organizó la Lucha Antileprosa inspirada en los trabajos del Comité de Higiene de la antigua Sociedad de las Naciones. Los Servicios de Sanidad tenían que descubrir, aislar y tratar, los enfermos que vivían entre la población sana. Como primer paso se elaboró un censo de leprosos; [23] esto permitió hacer un mapa de los focos de lepra en el Protectorado. Se descubrieron dos núcleos, uno en el Lucus y otro en Gomara, fronterizos con la zona francesa, que tenia su principal localización en Fez. Para su aislamiento y tratamiento se construyó una leprosería en Larache junto al Atlántico.

Para combatir las enfermedades infecciosas, se organizaban periódicamente Campañas Sanitarias. La principal era la antivariólica, que inmunizaba a los nacidos en las ciudades, y con la colaboración de los Círculos Médicos llevaba la vacuna, hasta los más alejados aduares de las cabilas. [24] 


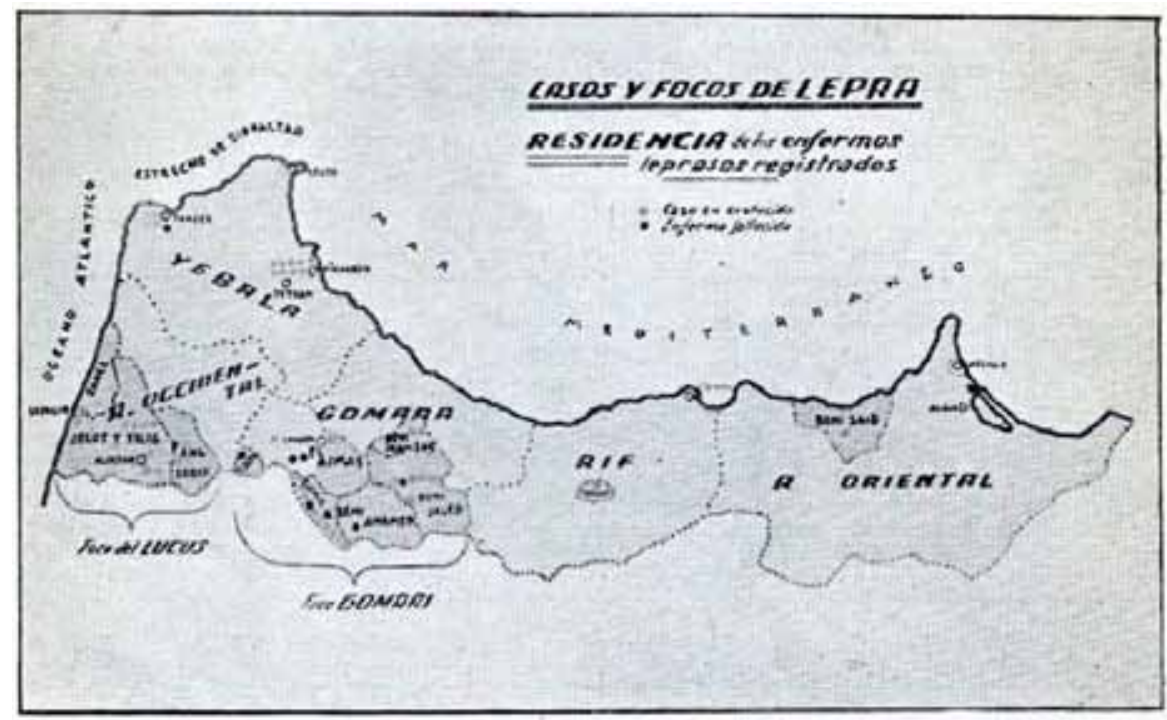

Fig. 23. Focos de lepra.

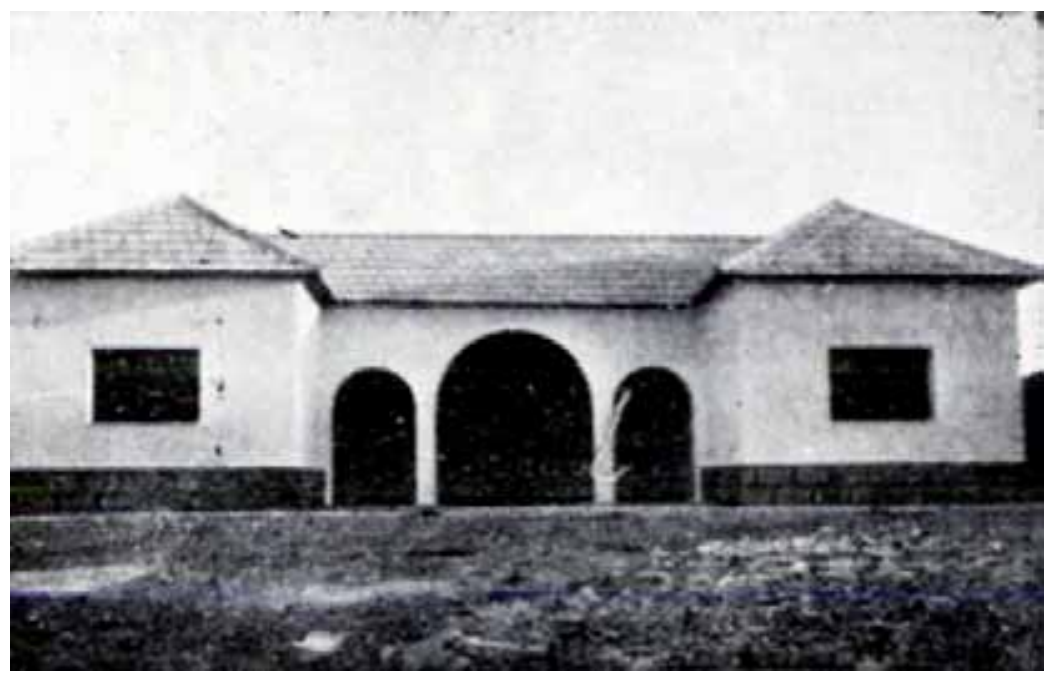

Fig. 24. Consultorio veterinario en el Telata de Beni Ahamed.

Contra las fiebres tifoideas, que afectaba a poblaciones con huertas regadas con aguas residuales, se sanearon los abastecimientos y las fuentes de agua para el regadío.

Se emprendió una Campaña antidiftérica con la vacunación periódica de los escolares. 
Las tiñas tenían una gran difusión especialmente entre los niños. El tratamiento con talio o Rayos X, difícil de aplicar, es imposible en el ambiente rural. Se aconsejó separar los niños afectos de tiña, en un aula aislada, separados de los sanos.

En los primeros tiempos se presentaron casos de tifus exantemático, en la región del Kert. La lucha se centró en la destrucción del piojo, tarea complicada por la abundancia y la frecuencia de parásitos en la población rural. Posteriormente se vacunó masivamente a la población y la epidemia no se generalizó. Los últimos casos se dieron en el año 1941.

Se proyectó una Campaña para la construcción de fuentes, pozos y acometidas de agua potable, para aumentar las prácticas higiénicas de los marroquíes de los aduares y disminuir las enfermedades parasitarias, digestivas y de la piel.

El Gobierno Español se preocupó de la formación de personal sanitario marroquí. Con este fin protegió y subvencionó el estudio de marroquíes, que demostraban aptitudes y ambición, en centros de enseñanza media y en universidades. Dos de los licenciados en medicina, los doctores Ben Aomar y Mohamed Skyres regresaron a su país y eran los únicos médicos marroquíes en la Zona Norte de Marruecos cuando se declaró la Independencia. Otros después de licenciados, se establecieron en la Península.

También se instaló en Tetuán una escuela para la formación de sanitarios, comadronas y enfermeras marroquíes, que fueron de gran utilidad. En especial los sanitarios eran jóvenes inteligentes, fieles, con una formación básica discreta, un solo curso, pero con unas ganas enormes de trabajar, de ser útiles y de aprender, cosa que hacían con gran rapidez si procurabas enseñarles. Fueron fundamentales y una ayuda imprescindible para el médico rural. [25]

La organización de la Sanidad, en el Protectorado, en especial desde la guerra civil, con la planificación del Dr. Solsona, era en teoría muy buena y consiguió llevar a las ciudades los beneficios médicos y terapéuticos propios de aquellos años, y hasta la cabila más alejada de las capitales, llegaron los médicos para introducir una medicina científica y práctica. 


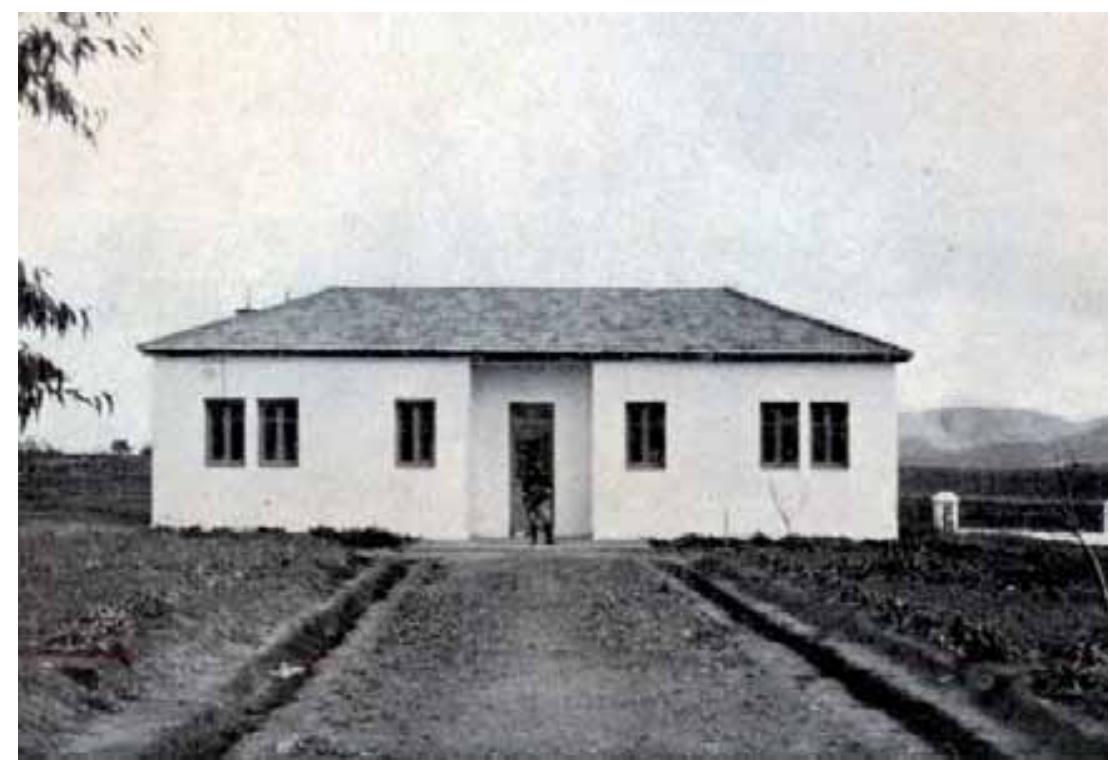

Fig. 25. Consultorio médico en Targuist.

Como es lógico, en las ciudades y en especial en Tetuán, la capital, los Servicios Sanitarios, la edificación de Centros y Hospitales, y el buen funcionamiento de sus actividades, fueron mucho más completos, que en las zonas apartadas, de difícil acceso, donde la buena voluntad, no es suficiente para su control.

Algunos proyectos eran imposibles de realizar. La idea de disponer de ambulancias que trasladaran los enfermos que necesitaban intervenciones o cuidados especiales a hospitales, era una fantasía, si se conocía bien el terreno. Es posible que algún enfermo fuera trasladado desde Uadras o Anyera a Tetuán, pero por los caminos angostos del Ajmas, Guesaua, Beni Ahmed, Beni Jaled, Tabarrant, Tagsut, Beni Ammart, Beni Tusin, etc., nunca circuló una ambulancia.

Igualmente el transporte de muestras para su análisis al Laboratorio Central de Tetuán.

La Campaña para construir fuentes que abastecieran de agua potable a toda la población, instaló algunas en núcleos urbanos que disponían de aguas subterráneas o de corrientes superficiales, pero en la mayoría de las cabilas, no 
existía agua en el subsuelo o por lo menos no se conocía su existencia, y las corrientes superficiales eran escasas, irregulares, y desaparecían durante los meses de verano.

\section{Los médicos de los Servicios Sanitarios de la zona norte de Marruecos. El inicio de mi destino en Marruecos [26]}

Para un mejor control del sistema sanitario, para poder dirigir y unificar las actividades de los médicos, ofrecer a estos una mayor protección y seguridad en su estabilidad y en su trabajo, y una mayor coordinación de los servicios, la Dirección de Sanidad y Higiene Pública, incluyó, dentro de la Organización de la Dirección de Sanidad e Higiene Pública, la sección sexta, con la misión de organizar las profesiones sanitarias de la Zona.

Fue una labor personal del Dr. Solsona. Consiguió de la Dirección General de Sanidad en Madrid, que se creara el Cuerpo de Médicos de los Servicios Sanitarios de la Zona Norte de Marruecos que dependía directamente de la Presidencia del Gobierno. Se ingresaba por oposición libre. Se formó un escalafón único, tanto para los que ocupaban plazas en los hospitales, como para los destinados en zonas rurales. Los aspirantes eran controlados meticulosamente, al presentar las solicitudes: la guardia civil solicitaba informes a la alcaldía, al párroco y a las tiendas vecinas al domicilio del solicitante. Se tenían muy poco en cuenta los antecedentes políticos del aspirante, y se daba mucha importancia a la conducta y a la moralidad de la persona investigada. Si esta era conocida como un amante de la juerga, de la bebida, del juego o del sexo, no era aceptada.

Antes de comenzar el primer ejercicio, se pasaba un examen físico y eran excluidos los que padecían alguna enfermedad crónica, lesiones valvulares, asma, o algún defecto orgánico que pudiera disminuir su actividad física. Las especialidades, en los hospitales, se cubrían por oposición restringida entre los que pertenecían al Cuerpo.

En el año 1940 se celebraron las primeras oposiciones y fueron incluidos en los primeros números del escalafón dieciséis médicos que ya trabajaban en centros sanitarios, y diez médicos civiles que aprobaron esta primera 
oposición. Estas fueron celebrándose anualmente, hasta el año 1944; después se convocaron los años 1949, 1951 y finalmente en 1954, a la que me presenté. En esta última se ofrecieron diecisiete vacantes y entre los aspirantes había diecisiete interinos, más un ex interino. Todos los ejercicios eran eliminatorios. En el primero, oral, de ciento cincuenta temas, desarrollabas cuatro: medicina, cirugía, higiene y sanidad. En el segundo examinabas, diagnosticabas e instaurabas un tratamiento en un enfermo del Hospital Civil de Tetuán. En el tercero preparabas, examinabas al microscopio, e identificabas, plasmodium, leishmanias, treponemas, bacilos de Koch, etc., y en el cuarto practicabas sobre un cadáver, una técnica de cirugía menor, como una ligadura arterial, una sutura o la amputación de una falange.

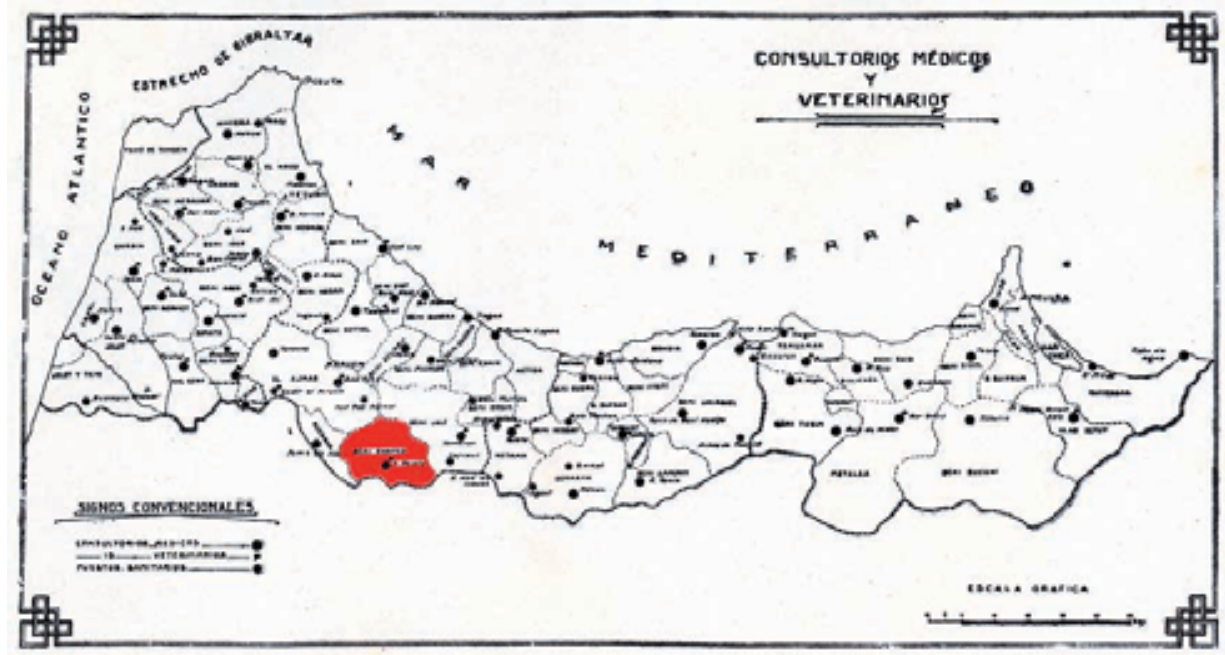

Fig. 26. Mapa del Protectorado y situación de la cabila de Beni Ahamed (en rojo).

En los ejercicios celebrados en Madrid en noviembre de 1953 y en Tetuán con el mismo tribunal, en enero de 1954, acudimos unos ochenta opositores. Después del cuarto ejercicio, quedamos quince. De los quince, trece eran interinos.

El presidente del tribunal era el profesor de Microbiología e Higiene y Sanidad de la Facultad de Medicina de Madrid, don Valentín Matilla. Era un hombre serio, justo y exigente, Presidente de la Real Academia de Medicina y Presidente perpetuo de todos los tribunales relacionados con la Sanidad de Marruecos y de las Colonias. 


\section{La sanidad en los Centros Médicos rurales durante los últimos años del Protectorado [27]}

Nuestra labor se ejerció principalmente en los consultorios rurales. El Telata de Beni Ahamed, en el año 1954, es una de las cabilas más secas y pobres del Protectorado, y figura como modelo de cabila desértica, en la Guía Turística de Marruecos de Antonio J. Onieva del año 1947. El terreno es accidentado, el suelo de pizarra, no existen rocas ni tierra cultivable.

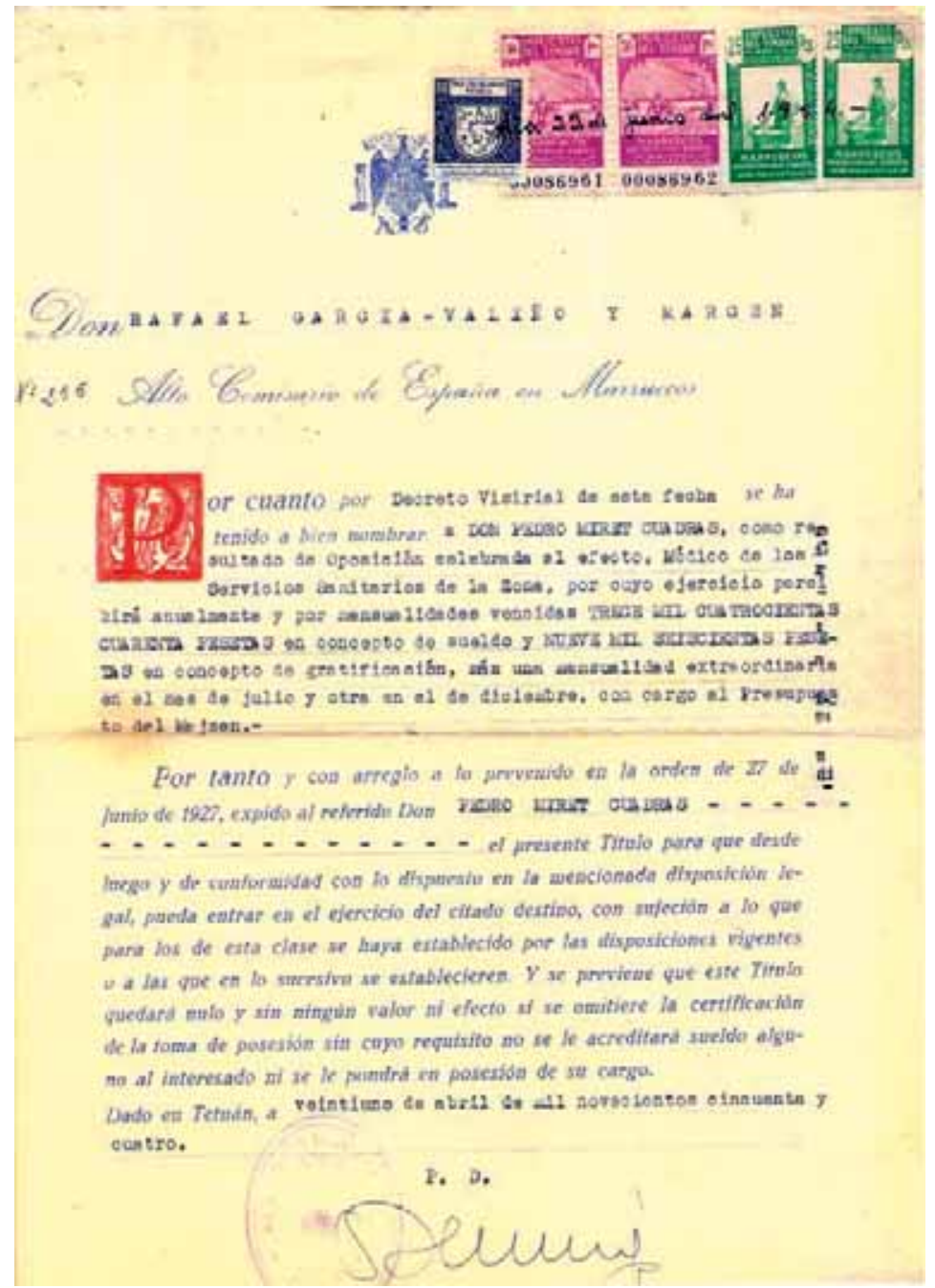

Fig. 27. Nombramiento del doctor Pere Miret, 1954. 


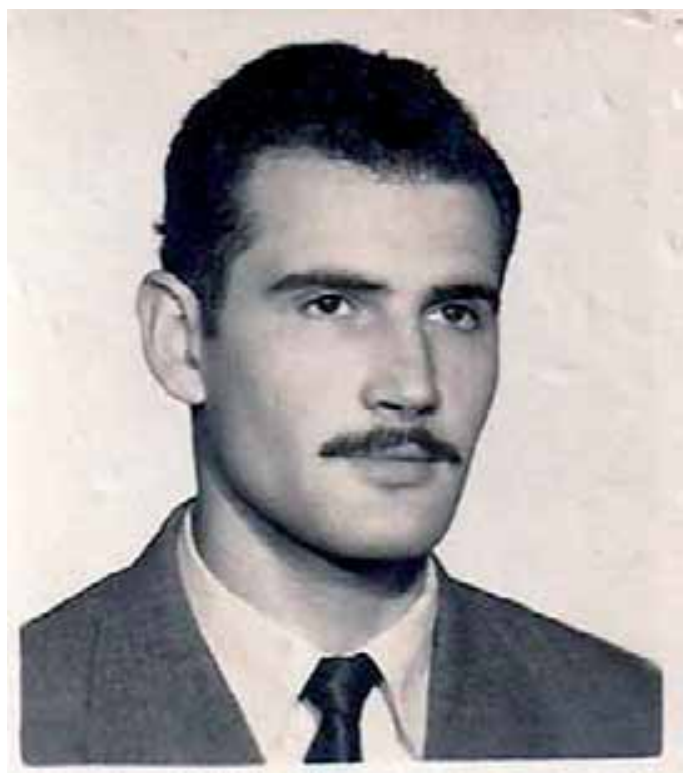

Fig. 27 b. Doctor Pere Miret Cuadras.

El río Tesaraf, un modesto afluente del Uarga, era la frontera con el Protectorado francés, un riachuelo el Aulay la separa de Beni Jaled, y el Audur de Guezaua. De abril a noviembre quedan reducidos a unas hoyas que juntamente con las charcas que persisten en alguna vaguada, son la única reserva de agua de muchos de los poblados de la cabila. No crecen árboles, tan solo en algunas hondonadas umbrías, que mantienen la humedad del agua que se escurre por sus laderas en la temporada de las lluvias, y donde queda depositado el polvo y restos vegetales que arrastra el viento, crecen algunas higueras y olivos. Los matorrales de hoja dura y espinosa y el lentisco, con su pequeño fruto rojo granate, ocupan la parte de su territorio que permite el crecimiento de estos arbustos. En alguna superficie inclinada, triturando la pizarra, con arados romanos arrastrados por personas, en general mujeres, sembraban avena, que si llegaba a madurar, molían a mano entre dos piedras, para cocer panes planos y duros. [28]

El desplazamiento dentro la cabila se efectuaba por veredas construidas por el paso del hombre, y no existía ni un solo vehículo de ruedas de tracción animal, ni un sendero por donde pudiera circular. Se viajaba a pié y eran escasos los que disponían de un mulo. 


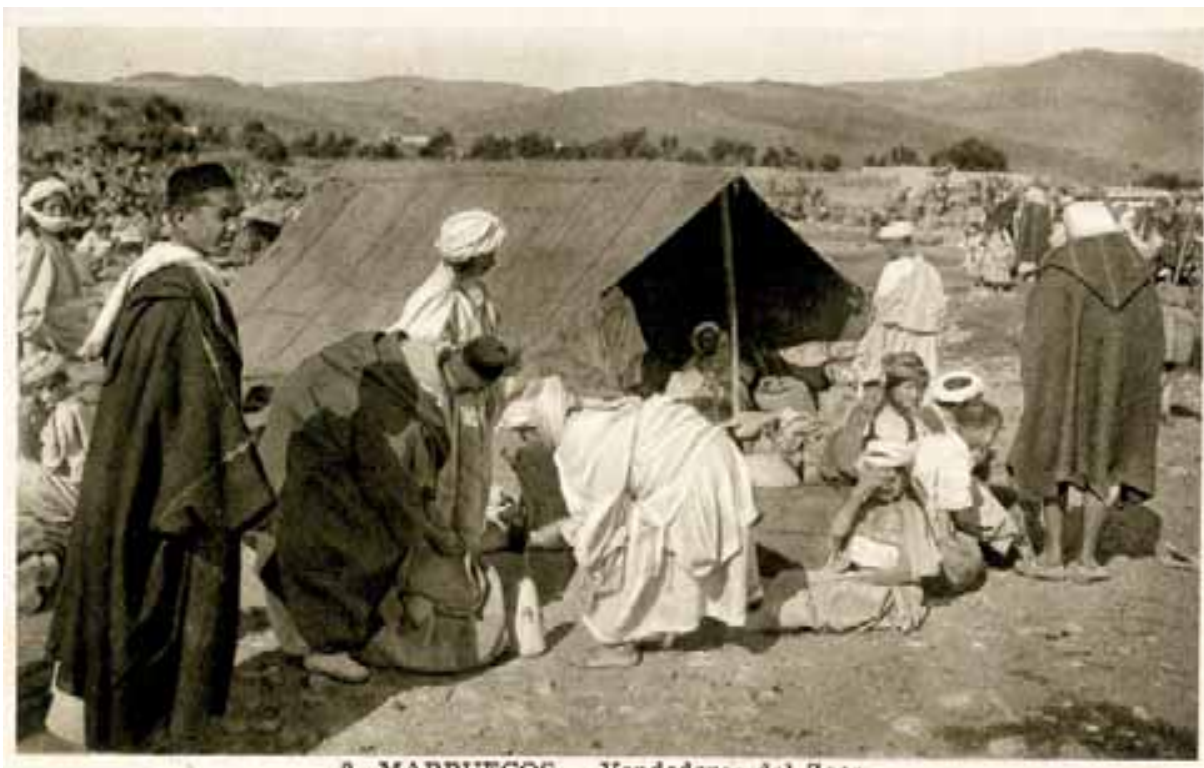

8 MARRUECOS - Vendedores del Zoco

Fig. 28. Vendedores del zoco.

El personal de la Intervención era el interventor, ayudante, administrador, escribiente, veterinario, médico, teniente de la mejasnía y esposas respectivas. El edificio se abastecía del agua de un único pozo, que existía a dos o tres horas de camino y que unos presos cada mañana, en vasijas de barro de unos cuarenta litros de capacidad, a lomos de un mulo, trasportaban a domicilio, y vertían dos se ellas en un viejo bidón de hojalata. No había más. Esta agua alcanzaba para beber, cocinar, afeitarse, fregar el suelo una vez por semana, lavar la ropa, lavarse los pies, limpiar el retrete y regar una florecilla que procuraba sobrevivir en la ventana. En la vivienda, existía un cuarto de aseo alicatado blanco, con lavabo, ducha, bañera, bidé y váter, pero no había conducción de agua y nunca salió una gota de sus grifos.

Llueve algunas veces de noviembre a marzo, pero nunca recogían el agua de lluvia. El resto del año es seco y caluroso, con temperaturas habituales en verano de $40^{\circ}-42^{\circ}$.

Por debajo de las placas pizarrosas viven multitud de gusanos y lombrices que son el alimento de las gallinas enanas que corren sueltas por los poblados y ponen unos huevos proporcionados a su envergadura. 
Unas cabras del tamaño de un zorro, que comían la corteza de las ramas, y la hoja dura y espinosa de los matorrales, cuando podían alumbraban un cabrito, que con las gallinas enanas, eran el único subministro de proteínas de la comunidad. Las cabras no se ordeñaban; la leche solo alcanzaba para la alimentación del chivo.

Un ramal que salía de la carretera general en Bab Taza, conducía al zoco de Telata de Beni Ahamed, después de recorrer treinta y cinco o cuarenta kilómetros. Los primeros cinco o seis, hasta un antiguo asentamiento de la legión en Puente Melha, tenían un firme de piedra; luego la pista se empinaba por caminos terreros, tortuosos, inseguros, deslizables, en especial cuando llovía, que hacían difícil y a veces imposible el paso de la Valenciana, los días de zoco. Los presos distribuidos por el trayecto y controlados por mehasnis, vigilaban y arreglaban, como podían, los deslices de los bloques de pizarra en las curvas cerradas de la montaña, para evitar el despeño del carruaje.

Este trasporte, procuraba entregar el correo, surtir algunos tenderetes, cargar paisanos de poblados más o menos cercanos al trayecto, gallinas, cabras, y en alguna ocasión, algún funcionario de la cabila que tenía siempre reservado el asiento, al lado del conductor.

El médico, tenía unos enemigos permanentes, contra los que era necesario luchar y vencer: la soledad, y el aislamiento: estaba solo. Era el guardián de la salud de veinte mil seres humanos dispersos en un espacio de $500 \mathrm{~km} 2$, expuestos a todo tipo de traumatismos, de enfermedades infecciosas, carenciales y degenerativas, que malvivían mal alimentados, en viviendas primitivas, en pésimas condiciones higiénicas, que carecían de desagües y se calentaban, en invierno, quemando raíces y abriendo un agujero en el techo para dar salida al humo. Estas personas, unas antes, otras después, y algunas nunca, cuando se convencían de los beneficios que les reportaban sus actuaciones sin pedirles nada a cambio, solicitaban tu ayuda, se mantenían fieles, y se convertían en amigos leales. [29]

Tenía un ayudante musulmán con una formación adquirida en un curso en la escuela de sanitarios de Tetuán, y una llamada enfermera, antigua cantinera durante la guerra de ocupación, que sabía el idioma castellano, aprendido de los soldados. El primero, inteligente, excelente persona, trabajador y con unas ganas 
enormes de aprender, fue indispensable para el trabajo; la segunda, anciana, arrugada, gran fumadora, con un conocimiento inusual de la naturaleza humana, informaba de las intenciones, de la conducta, de las costumbres,... de los que acudían a la consulta.

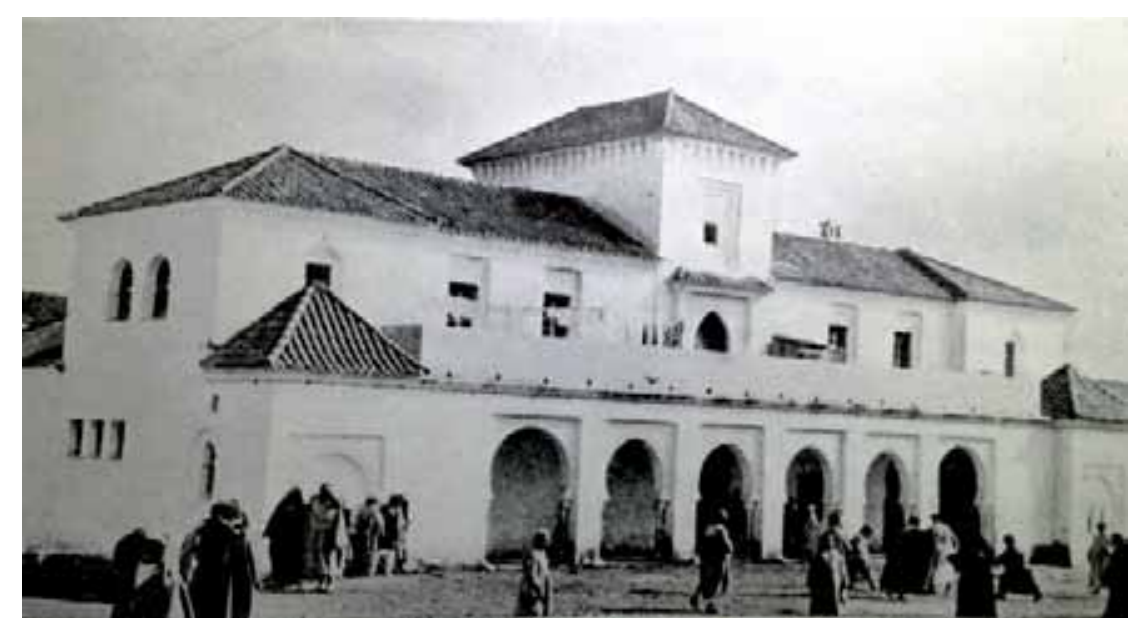

Fig. 29. Escuela del Telata de Beni Ahamed.

Disponía de un Consultorio, de unos medicamentos eficaces contra enfermedades frecuentes, material de curas, y tres camas. Estos Centros construidos a principio de los años cuarenta conservaban una buena estructura material, los medicamentos llegaban cada trimestre, el utillaje, agujas, pinzas, bisturí, suturas, guantes, era insuficiente y deteriorado, se esterilizaba hirviendo en un cazo o sumergido en alcohol, y las camas estaban en un estado lamentable.

Más importante que el material eran sus propios conocimientos. No es posible conocer todas las ramas de la medicina y de la cirugía. Ningún Centro rural estaba preparado para atender a determinados enfermos, y pese al proyecto inicial, ningún paciente fue trasladado nunca de uno de estos Centros a un hospital. El aislamiento era total, no existía luz eléctrica, ni comunicación telefónica, no era posible hablar con algún compañero, ni salir de la Intervención. No había vacaciones de verano, cuando el paludismo llegaba a su máxima frecuencia, normalmente marchábamos una vez al año de Navidad a Reyes. Pasábamos un año sin salir de la cabila. Tu mundo social se reducía a la compañía de los seis funcionarios y sus esposas. 
Esta situación no favorecía el trabajo. El médico en la Intervención no tenía el más mínimo control. La ciudad quedaba muy lejos, nunca un círculo rural recibió la visita de un delegado de sanidad, de alguien que tuviera un interés real, para comprobar como funcionaba la sanidad rural.

El trabajo, la actividad, la dedicación, la atención, que el médico dedicaba a sus enfermos dependían única y exclusivamente de su sentido de la responsabilidad, de su ética personal, del amor a la profesión, y de su concepto de la caridad. El cabileño no era exigente, ni podía exigir, si se sentía bien atendido y mejoraba volvía, y no siempre, sino, no protestaba, ni reclamaba, te ignoraba.

El Director de Sanidad no salía nunca de su despacho, y naturalmente fiaba en las declaraciones y estadísticas que se le mandaban a final de año. Esto favorecía que algún profesional se desanimara, perdiera interés y se limitara a repartir medicamentos sin un examen correcto de los pacientes y a inventar las estadísticas, reduciendo los casos anuales de enfermedades infecciosas, de declaración obligatoria, en un porcentaje que dejaba contenta la Dirección.

Quizás un ejemplo, de cómo el aislamiento puede alterar la conducta de un profesional, ilustrará mejor esta situación. Cuando nos incorporamos al Consultorio de Beni Ahamed, el microscopio, sin el cual es muy difícil diagnosticar correctamente el paludismo, e imposible diferenciar sus variedades, estaba inservible. Se envió al depósito de material y nos fue devuelto reparado.

A final del año 1954, mandamos la Memoria de la Lucha Antipalúdica a la Dirección de Sanidad, [30] con la separación de los casos por las variedades de vivax, malarie y falcíparum, la variedad maligna tropical, y nos fue devuelta, con un oficio del Director, en el que nos amonestaba, y nos advertía de que era imposible que las cifras que aportábamos fueran correctas, ya que él disponía de las memorias de años anteriores y los datos que contenía la nuestra, eran incompatibles con los que a él le constaban como reales. Nos ordenaba que la rehiciéramos, poniendo más atención en su redacción. Me vi obligado a remitir una copia de los oficios de envío y de devolución, del microscopio, este firmado por el, y ofrecerle los libros de registro, en blanco, de los años anteriores. 


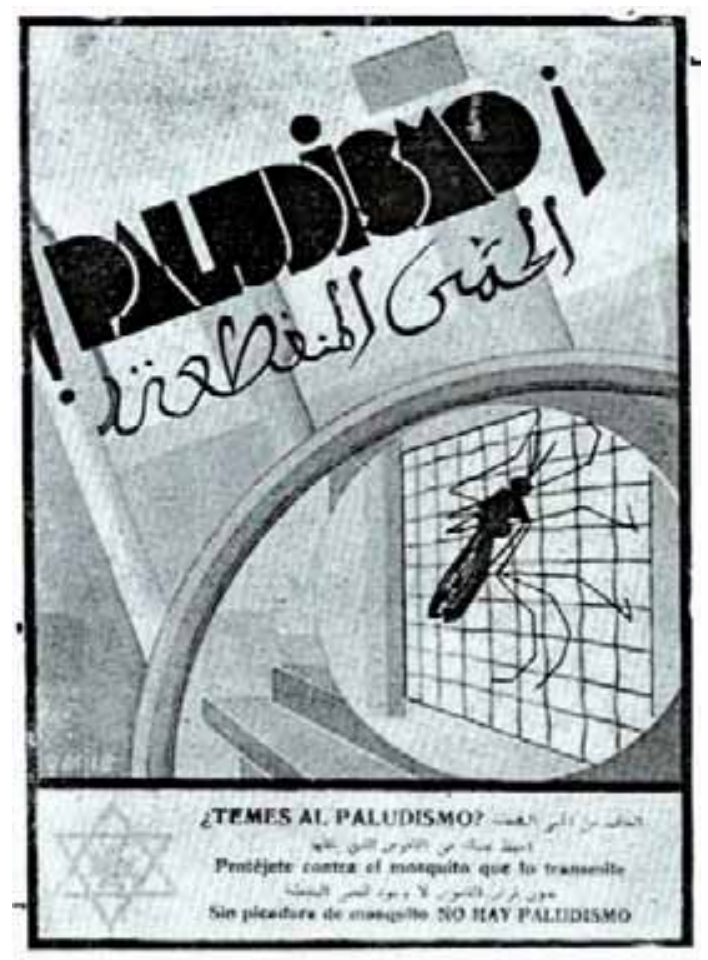

Fig. 30. Cartel de lucha contra el paludismo.

Estos casos, no se pueden generalizar, y muchos médicos suplieron la falta de medios, dedicando todo su tiempo, todas sus energías, y exprimiendo toda su inteligencia, para poder atender la variada patología de los cabileños, pero demuestran que las estadísticas, aunque la situación sanitaria del país era evidentemente mucho mejor que al principio del Protectorado, probablemente era menos favorables, en el campo, que la que mostraban los datos que facilitaba la Dirección de Sanidad.

El Consultorio se abría a las nueve de la mañana [31] y se cerraba cuando no quedaba ningún enfermo. En los días de zoco, frente a la puerta del Consultorio, se agrupaban doscientas o más personas. Con Hach Hamed el sanitario, y Rahma, los separábamos por grupos. Los que acudían, por primera vez, los consecutivos, que habitualmente habían perdido el carnet que se les entregaba con los datos de su enfermedad, los que tenían fiebre, los que presentaban lesiones visibles de piel, de ojos, de boca, de genitales, los que tenían un estado general deplorable, los traumatizados, los niños. Cada grupo tenía su protocolo. 


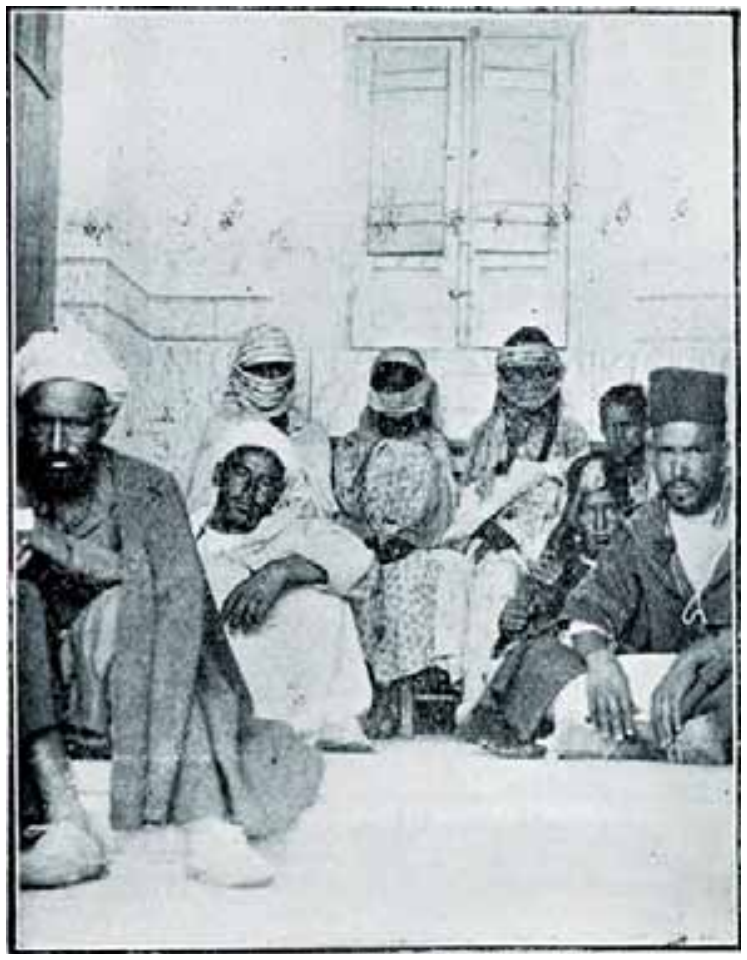

Fig. 31. Pacientes esperan para pasar consulta en un consultorio médico.

El paludismo había descendido, pero no desaparecido. Dos de cada tres palúdicos eran recidivantes, habían recibido tratamientos diversos, incompletos o inapropiados, habían cronificado su enfermedad, sufrido reinfecciones, el bazo hipertrofiado [32] ocupaba la mitad de la cavidad abdominal, y padecían una anemia hipocroma permanente. El tratamiento con atebrina y plasmoquina les mejoraba, pero el reservorio que albergaba el bazo, era resistente al medicamento, el enfermo recidivaba a los pocos meses, y era un depósito permanente de plasmodium, que no permitía la extinción del paludismo.

Los que enfermaban por primera vez, si cumplían el tratamiento, curaban, pero esto no era fácil. Se les entregaba el medicamento para dos, tres o cuatro días, según su lugar de residencia, y dada la eficacia de la medicación, muchos cumplían y volvían de nuevo para continuar el tratamiento, pero otros abandonaban con la mejoría, y pasaban a enfermos crónicos. 


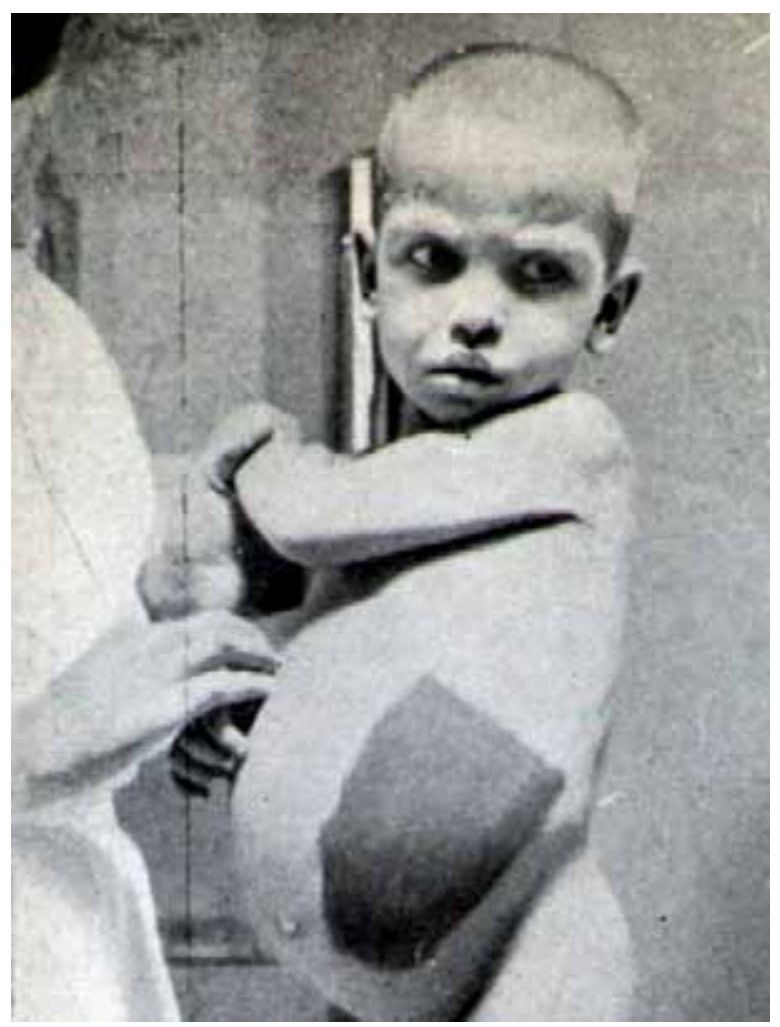

Fig. 32. Hipertrofia del bazo en un enfermo de Kala-azar.

En el segundo semestre del 1954, declaramos 90 enfermos de paludismo, 26 eran nuevos, y 64 recidivantes, crónicos, que eran más de los que se esperaban.

Los comprimidos de atebrina son de color amarillo, y fue tanta la confianza en la bondad de este medicamento, que ellos llamaban eddua safra, que cuando sustituyeron la atebrina por la cloroquina de color blanco, eddua beida, la lanzaban a la puerta del Consultorio reclamando eddua safra, misiana bisef.

Para la profilaxis se pulverizaba el interior de las viviendas con una solución líquida de D.D.T., dos veces al año. El procedimiento era eficaz, y además exterminaban pulgas, piojos, chinches y garrapatas, aunque hoy está proscrito por tóxico. Para destruir las larvas era necesario recubrir las charcas con una capa de petróleo. La dificultad estaba en que casi siempre, esta era la única agua de que disponía un poblado y no era posible su petrolización. 
También la sífilis continuaba activa y extendida entre la población. Como en los primeros años de Protectorado, la proporción de infectados, sin lesiones externas visibles, era muy alto. De cien pacientes que acudieron al Consultorio por otras dolencias, fueron positivos el 60\%, a tres pruebas de floculación, patognomónicas de sífilis activa, Kahn, Mainich II y Citocol. Estos enfermos, frecuentes en poblaciones con un alto índice de contagios, sufren reactivaciones periódicas y mantienen una endemia permanente.

Las madres continuaban trasmitiendo a sus hijos una sífilis congénita, e introduciendo nutrientes a sus bebés con alimentos masticados, ensalivados y contaminados con treponema, contagiándoles una sífilis adquirida y contribuyendo a la alta mortalidad infantil que tenía este pueblo. [33]

En los enfermos agudos, con sífilis primaria o secundaria, que presentaban chancros, úlceras, condiloma, pápulas, el neosalvarsán intravenoso adquirió un gran prestigio, ya que les proporcionaba una mejoría rápida y la desaparición de estas lesiones visibles, aparatosas y muy contagiosas, pero igual que en el paludismo, los que tenían afectados los órganos, por tratamientos anteriores inadecuados o incompletos, y los que se creían curados y abandonaban antes de finalizar el tratamiento, adquirían nueva lesiones articulares, viscerales, gomas, tabes o una parálisis general progresiva.

A finales del año 1955, se suministró penicilina en solución oleosa de aceite de cedro. Un inyectable contenía 9 c. c. y 300.000 unidades por c. c. El preparado liberaba la penicilina lentamente durante diez días. Para el tratamiento de la sífilis, la OMS aconsejaba un único inyectable. Esto permitió tratar también a los niños, pero se necesitaba un trocar grueso, para el paso del aceite, y 9 c.c., dejaban el glúteo dolorido y magullado, y se enquistaban con facilidad. Tampoco la eficacia era tan brillante como suponía la administración, y los enfermos continuaban exigiendo las inyecciones intravenosas de neosalvarsán. Estas se acreditaron de tal manera que, hasta el final del Protectorado, muchos enfermos con cualquier enfermedad, acudían al consultorio pidiendo por favor una inyección intravenosa, el ibra (aguja) barakaloufic o schuca (pinchazo) y no había manera de que concretaran, tan solo repetían una y otra vez: el ibra barakaloufic!

La prostitución estaba tolerada y reglamentada. Las tres "lailas misianas" 
ejercían su profesión en un barracón de barro, donde cabían, justos, tres camastros separados por una modesta mampara. Los días de zoco se formaban largas colas de individuos, frente a la cabaña, que protestaban de la larga espera, y en especial al atardecer, reñían con furia, cuando las chicas, agotadas, querían cerrar, y quedaban usuarios por atender.

Ellas tenían la obligación de acudir al Consultorio una vez al mes, donde se les exploraba y se recogía moco del fondo de saco vaginal que se examinaba al microscopio, en busca del gonococo Gram negativo. Todas estaban afectadas por una gonococia crónica, resistente, y tenían la serología positiva a la sífilis. La legislación obligaba a las contagiadas, a abandonar su actividad hasta certificar su curación. [34]

Resistentes a todo tipo de tratamiento, inclusive a la penicilina de depósito, en solución oleosa, no era posible su curación, y sin posibilidad de ser sustituidas, el servicio seguía funcionando, pero también los clientes estaban ya infectados de sífilis y blenorragia y la cronificación de las enfermedades, comporta, que estas se toleren mejor, aunque aparezcan posteriormente, alteraciones orgánicas en próstata, testículos, huesos, articulaciones, ovarios, trompas, hígado, bazo, sistema nervioso...

Los niños padecían las consecuencias de la alta morbididad, en forma de sífilis congénita, y de oftalmía purulenta gonocócica, que conducía a la ceguera.

Enseñamos a alguna mujer de los poblados para que aplicara gotas de nitrato de plata a los ojos de los recién nacidos, y alguno conservó la visión y con ella la vida, pero la lues y la blenorragia continuaban siendo habituales, en las zonas rurales del norte de Marruecos, al final del Protectorado.

Todavía en los años cincuenta, en la cabila de Telata de Beni Ahamed de cada cien niños nacidos vivos, morían, durante el primer año, más de la mitad. Las madres, mal alimentadas, cansadas, con el niño atado a la espalda alargaban por encima el hombro, o por debajo del sobaco, un pecho escuálido, que proporcionaba una leche escasa e insuficiente, y con frecuencia inexistente. Parientes, vecinos y conocidos, seguían masticando cualquier cosa que creyeran comestible, y se la introducían en la boca. El niño, no digería, se consumía, la diarrea era permanente, y quedaban tan solo unos ojos grandes y fijos que miraban asombrados, y que finalmente se apagaban para abrirse a la eternidad. 


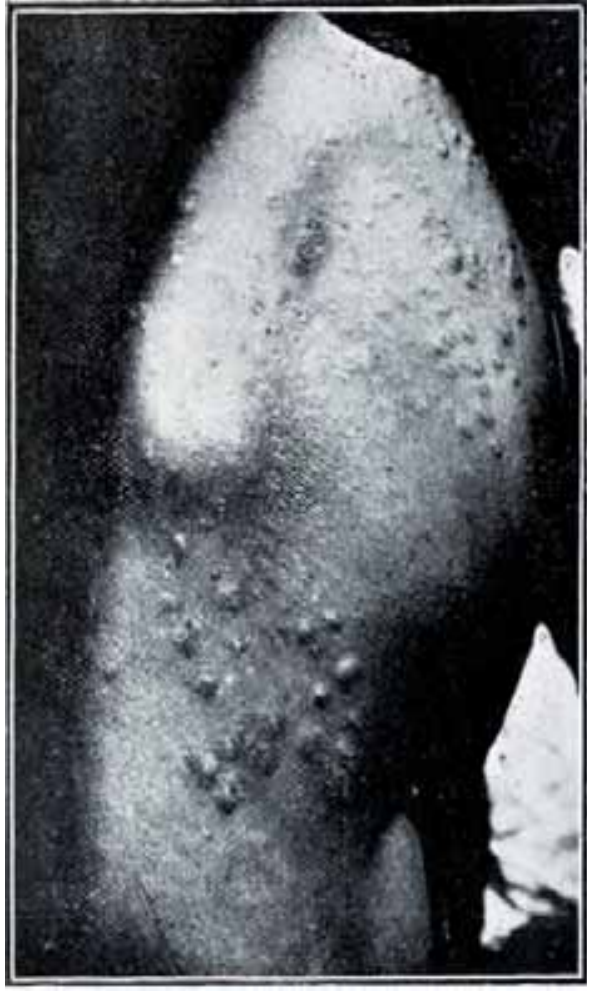

Fig. 33. Sifilis ulcerosa terciaria con deformación de las tibias.

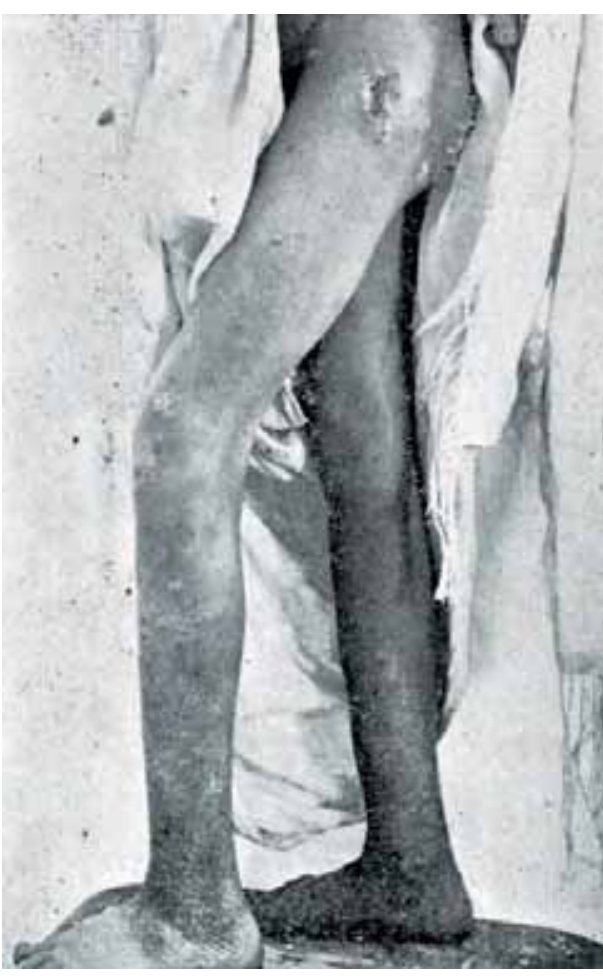

Fig. 34. Sifilis papulosa.

Eran pocos los padres que traían sus hijos pequeños a la consulta, estaban acostumbrados a la alta mortalidad infantil y la muerte de un lactante era un hecho normal. Para su tratamiento disponíamos de suero fisiológico subcutáneo, pero no había ninguna posibilidad de proporcionarle un alimento apropiado.

La conjuntivitis era estacional, pero cuando llegaba la época acudían a centenares y la falta de higiene comportaba sobreinfecciones, y algunas úlceras de cornea. En un cubo de agua del pozo, disolvíamos la cantidad adecuada de sulfato de cinc, y les entregábamos un frasco de la solución para lavarse los ojos, y un midriático en caso de úlcera. Otros con impétigo, pústulas, costras, eran friccionados con minio, un colorante, antiséptico potente, que contiene plomo y puede provocar saturnismo, pero que los dejaba limpios en pocos días. En la cara empleábamos el óxido amarillo de mercurio. 
La viruela había desaparecido con la vacuna, la difteria, y la tos ferina, eran ocasionales, el sarampión inexistente y la tuberculosis en el campo, rara, por la baja densidad de población.

La complexión, la frugal alimentación, y el ejercicio, deambulando siempre a pie, habían eliminado la hipertensión, el infarto y el ictus, en el campo, no en la ciudad.

Los heridos y los enfermos quirúrgicos, formaban un grupo complejo y nada fácil.

Disponíamos para la anestesia de cloroformo y de cloruro de etilo. Este último indicado para la anestesia local, puede ser usado para la anestesia general, aunque es peligroso, ya que el margen entre insensibilidad y paro cardíaco, es muy estrecho, pero tiene la ventaja de que se recupera la consciencia, poco tiempo después de retirarlo. La manera de usarlos, era goteando el líquido encima de un pañuelo colocado sobre la nariz del paciente. Vistas las ventajas y desventajas de uno y otro, adoptamos el cloruro de etilo, para los casos que requerían una anestesia general. No había autoclave, ni bata, ni gorro, ni guantes, y el instrumental quirúrgico era escaso y deteriorado. Se esterilizaba hirviéndolo en un cazo, o sumergido en alcohol. No se disponía de aparato de Rayos X.

Por suerte la naturaleza humana tiene unos recursos ignorados, y la inmunidad y la actitud mental del hombre que sobrevive en una naturaleza primitiva, salvaje y agresora, frente a una situación grave, es muy distinta de la que tiene un europeo condicionado siempre por el temor a la muerte. [35] Un ejemplo ilustrará mejor esta afirmación.

El primer domingo de julio de1955, a primera hora, tres cabileños llamaron a la puerta. Siempre sonrientes dijeron que en su poblado, una vaca había corneado un chico y este tenía las tripas fuera. La aldea, estaba a dos horas de camino. Era imposible tratarlo en su casa y les persuadí de que si seguía vivo, lo trasladaran al consultorio. A mediodía dejaban delante de la puerta de mi casa, unas parihuelas con un adolescente de unos catorce años, de cara redonda, muy colorado por el sol, que había recibido de pleno, durante el trayecto, y que me miraba tranquilo, sin ningún temor. Contestó a 
mi pregunta de cómo se encontraba, diciendo que notaba unas molestias en el vientre. Retiré la chilaba que lo cubría y apareció una gran margarita formada por las asas del intestino delgado, que salían por un agujero central y ocupaban toda la superficie exterior del abdomen. Los intestinos que habían salido al exterior, empujados por la presión interior del vientre, habían quedado estrangulados en el estrecho paso que permitía la abertura de la pared abdominal. Al movilizarlas, algunas placas necróticas se perforaron abocando el quimo sobre la entrañas. Pedí hablar con el padre del muchacho. Curiosamente entre los acompañantes, solo hombres, no había ni padre, ni hermanos, solo se presentó un pariente. Le expliqué, que colocaría las vísceras en el interior del abdomen, pero las posibilidades de que viviera eran prácticamente nulas, y seguramente moriría pronto. Cuando esto oyeron, se pusieron a gritar: Has de salvarlo, tu curaste a Hamed Ben Larbi de una puñalada, y a Abselam ben Aomar de la fractura de los dos brazos cuando lo apalearon, has de salvarlo! La cuchillada era extensa y aparatosa, pero no afectaba a ningún órgano importante, y las fracturas acaban por soldar, y no matan.

Me sentía impotente, pero sabía que tenía la obligación de intentar alguna acción. [36]

Vestido de calle, sin guantes, sin mascarilla, sin gorro, sobre la mesa que servía para cualquier exploración, con el Hach vertiendo gotas de cloruro de etilo sobre la nariz, comenzó la intervención. Ampliando el orificio y liberadas las asas aparecieron cinco o seis perforaciones en el intestino, que continuaron vertiendo su contenido en la cavidad abdominal. Con el calor sofocante del mes de julio y la angustia que me atenazaba, el sudor manaba de todo mi cuerpo y no podía impedir que de mi frente cayera a chorro dentro del abdomen abierto. Con agua del pozo limpiábamos lo que podíamos. El enfermo se movía, y si aumentábamos la frecuencia del goteo, aumentaba la taquicardia y los movimientos respiratorios disminuían. En este momento cambiamos el nitrito de amilo por cloroformo. El Hach se aplicaba en controlar el número de gotas por minuto, cuando los vapores de cloroformo le anestesiaron a él, que se desplomó inconsciente en el suelo, rompiendo el frasco de cloroformo. El enfermo despertó. Cuando el Hach recuperó la consciencia, reanudamos la intervención, de nuevo con cloruro de etilo. 
Pere Miret Cuadras

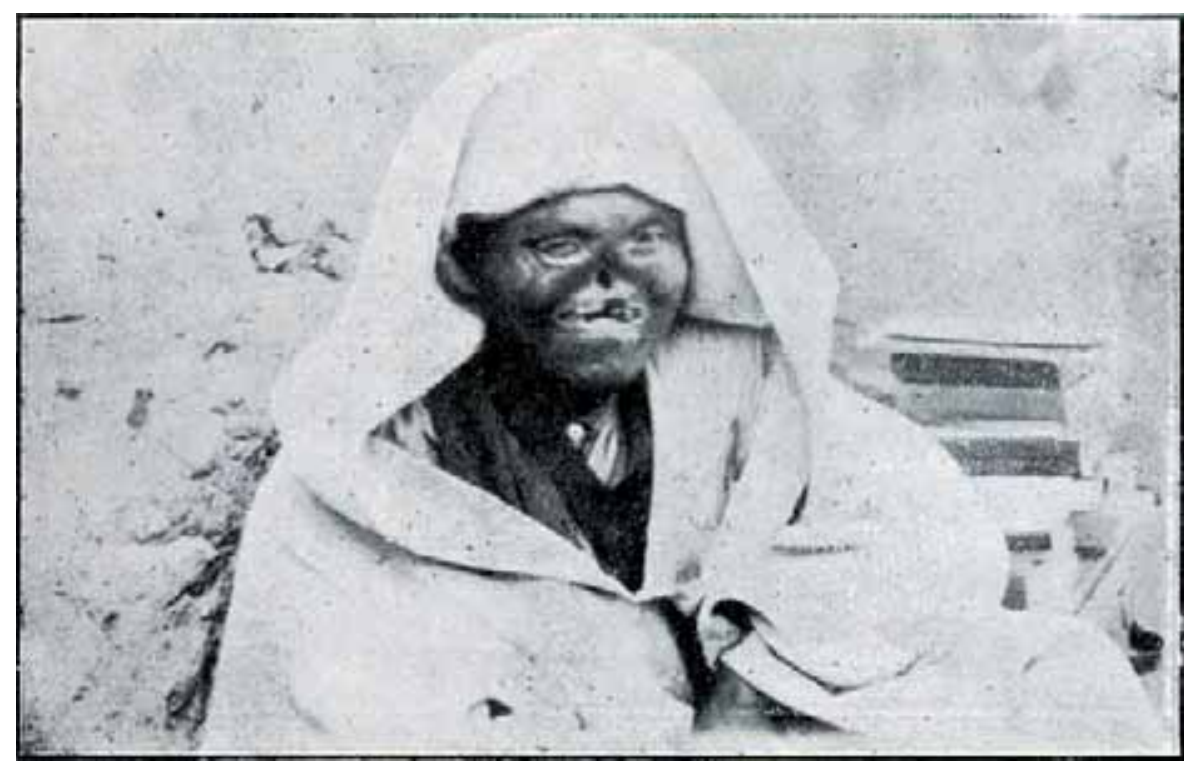

Fig. 35. Sifilis con lesiones en la cara.

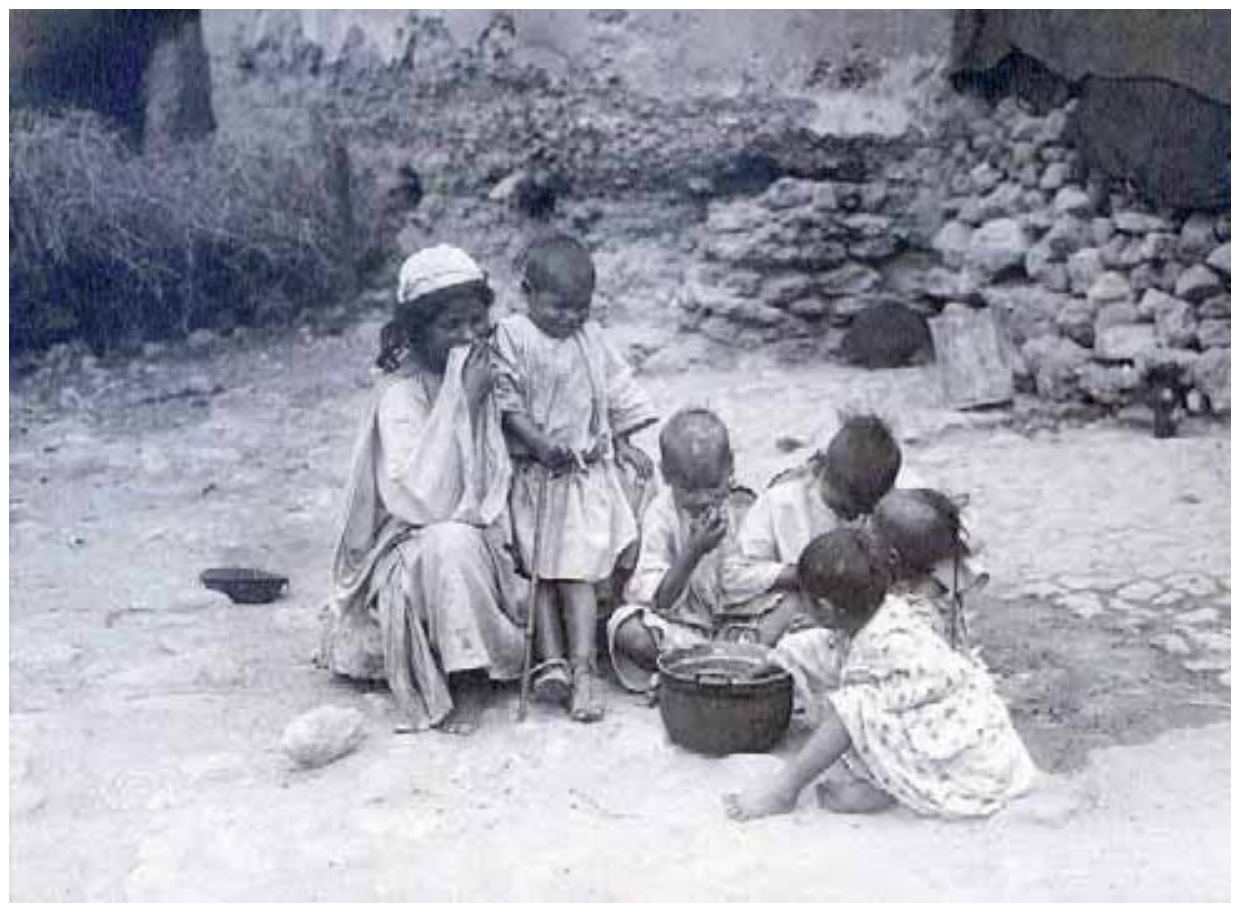

Fig. 36. Niños en el ámbito rural. 
Usando el sentido común, las superficies perforadas se invaginaron dentro de la luz intestinal, suturando la serosa por encima de la zona necrosada. Posteriormente descubrí que este procedimiento era ya, conocido y usado por los cirujanos.

Se dejó la herida abdominal abierta y un drenaje de Mikulicz. Se inyectaron 500 c.c. por vía subcutánea de suero fisiológico, y 9 c.c. de penicilina, de liberación lenta. Fuera los acompañantes salmodiaban: Allah akbar, Allah illa, ilahjla, Mohammed rasul Allah. [37]

En los zapatos se había acumulado una gran cantidad del sudor que se escurrió de mi cuerpo durante la intervención, como si hubiera metido los pies en un charco.

El joven fue instalado en una de las camas, con el somier roto, el colchón de borra desvencijado, sin sábanas, y sin mantas, cubierto con una chilaba. Era ya de noche y ninguno de los que le acompañaron quiso permanecer a su lado.

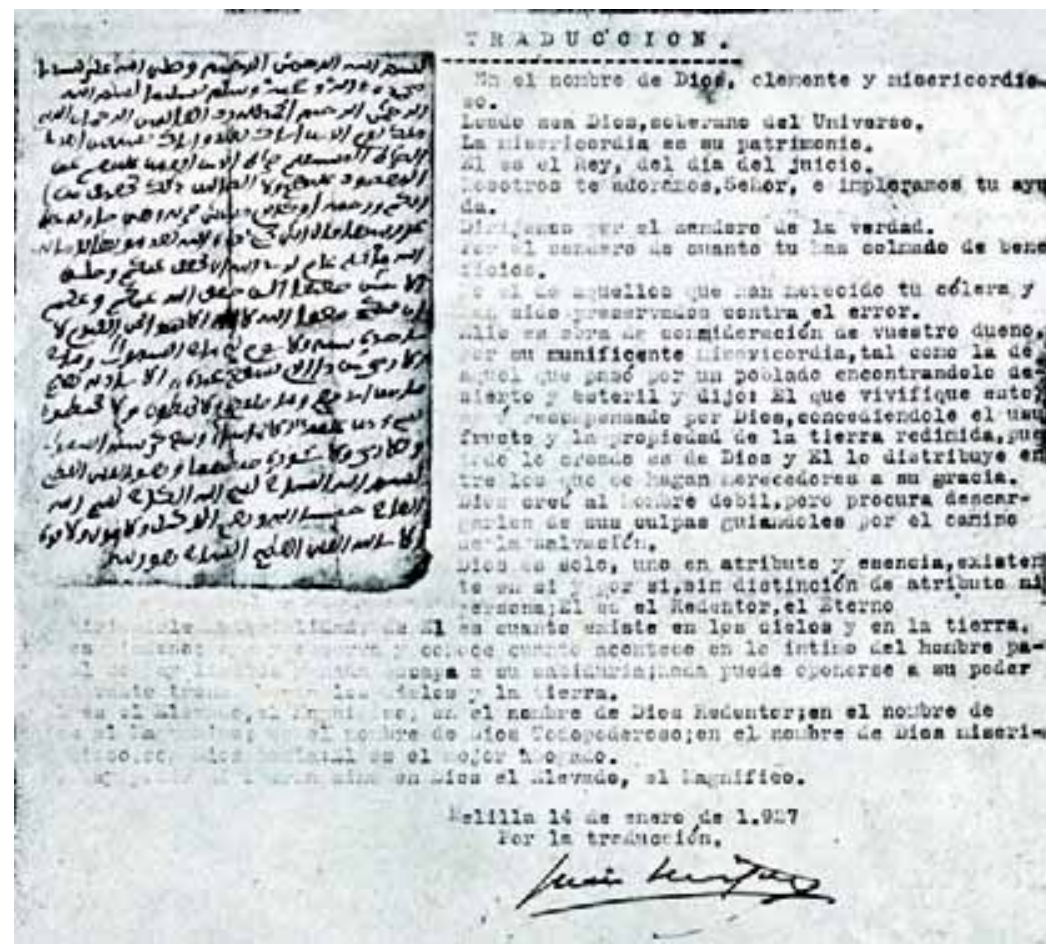

Fig. 37. Amuleto escrito. 
El Hach marchó a su casa y me quedé sentado al lado de la cama. El chico respiraba tranquilo, mientras yo meditaba cuan diferentes son las relaciones familiares, según la cultura, la educación, la tradición y la idiosincrasia de cada individuo. De madrugada me quedé dormido con la cabeza apoyada en su cama. Cuando desperté el muchacho me miraba sereno. A mediodía le dí unas cucharadas de agua que toleró perfectamente; a los dos días tenia movimientos peristálticos; a los tres ingería alimentos blandos; a los siete se marchó solo, a su poblado, con la herida no cerrada. Pasó todas las noches solo, nadie vino estos días a interesarse por su estado.

Este caso, sorprendente, no es único, tenemos otros parecidos que nos permiten hacer las siguientes reflexiones: Ningún europeo habría resistido doce o quince horas con las tripas fuera, sin padecer un shock traumático. Ningún occidental habría soportado que los intestinos eviscerados, durante horas, manoseados por manos que hurgaron para reintroducirlas antes de llevarlo al Consultorio, contaminados con polvo, con la suciedad de la ropa que lo cubría, con la sudoración del operador, con el agua del pozo sin hervir, perforados con salida de quimo, y suturadas las perforaciones con catgut sin esterilizar, fueran reintroducidos de nuevo en la cavidad abdominal, y no apareciera una infección, una peritonitis, una parálisis intestinal. A los pocos días recuperaron su función y sin más contratiempos, el herido reanudó su actividad habitual. [38]

Es posible que la penicilina de depósito que le inyectamos, en aquellos primeros tiempos de su uso, evitara alguna infección, pero aquellos intestinos fueron tan maltratados, que es imposible atribuir solo al antibiótico el resultado obtenido.

La comodidad y la facilidad para adquirir todo tipo de elementos que a nosotros nos libran de penalidades y enfermedades, inhiben nuestra capacidad de defensa. Por el contrario, la necesidad de luchar para subsistir, y las infecciones continuas, desarrollan en los sobrevivientes, el sistema inmunitario, y la resistencia mental del organismo.

La muerte para el marroquí del campo, no es ni una incógnita, ni una duda, ni una preocupación. No la aprecia ni la teme, la conoce, está familiarizado con ella, sabe que la vida cambia, no se pierde. La providencia es la que 
decide (mulana araf). Ha visto morir en su pequeña choza, a su lado, a sus familiares, los ha acompañado, sobre unas angarillas, sin caja, y ha abierto un hoyo con la cabeza orientada a la Meca, mientras parientes y vecinos le entregan al muerto, papeletas con recados, peticiones, o insultos, para los que ya residen en el más allá. El no se angustia, ni se horroriza, ni le entra un pánico incontrolado, como el que le entra al hombre refinado, que altera el sistema neurovegetativo, sus conexiones hormonales, y es causa de un shock mortal.

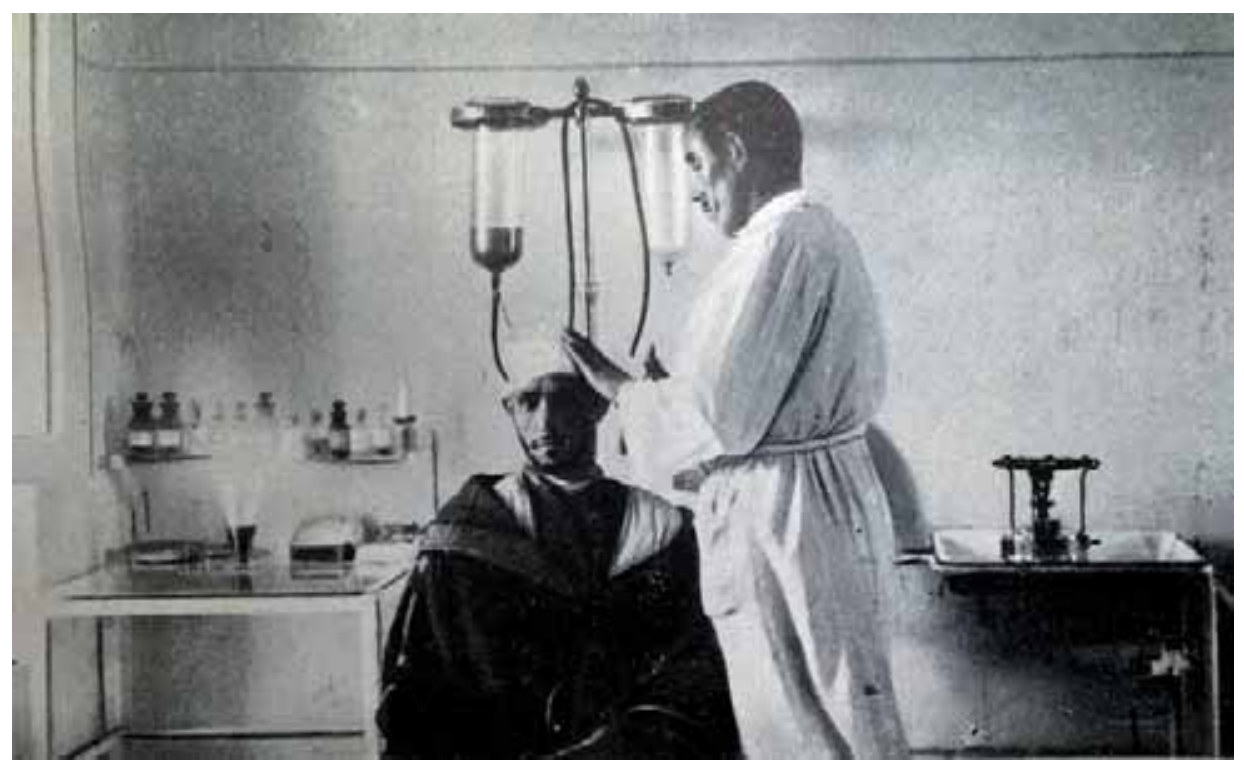

Fig. 38. Atención a un enfermo por parte de un practicante marroquí.

Repetidos casos nos ayudan a comprender la mentalidad de estas personas, el concepto de familia, el respeto a la tradición, la relación con los hijos y siempre al final, la recuperación milagrosa de la enfermedad. [39]

Una tarde me rogó un sujeto si podía ir a su poblado, donde su mujer, había dado a luz cuatro días antes, y el niño con las piernas y el cuerpo en el exterior, continuaba con la cabeza dentro de la barriga, a pesar de que todas las mujeres del poblado, habían tirado fuerte de las piernas del feto muerto, y le habían dado a beber, a la madre, versículos del Corán, macerados en agua. Al día siguiente de madrugada salimos a caballo, y llegamos al poblado después de cabalgar seis horas. Nos esperaban expectantes, las veinticinco o 
treinta personas, del lugar, que no habían recibido nunca la visita de un europeo. Como era costumbre, el padre no quiso llevarnos a ver la mujer, hasta que hubimos consumido unos vasos de te y una gallinita asada.

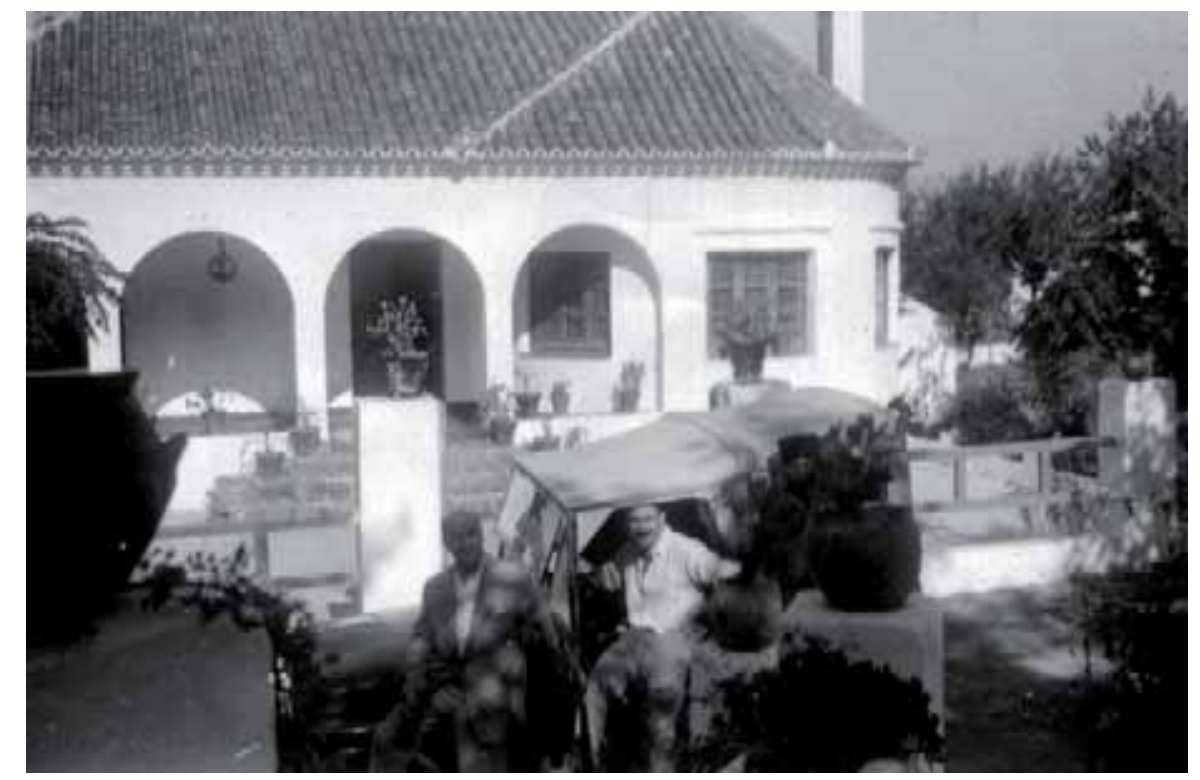

Fig. 39. Vivienda del Interventor, de Beni Ahamed. Jeep para su uso personal y exclusivo. Solo podía circular por la pista que unía el zoco con Bab Taza a $35 \mathrm{Km}$.

Después nos acompañó a una cueva de un metro y medio de altura, de cuatro o cinco de profundidad, uno y medio de ancho, y una sola abertura, la estrecha boca de la entrada. Allí había colocado a su mujer, porqué la pestilencia era insoportable. Penetrando a gatas, casi a oscuras, la mujer semiinconsciente tenía entre las piernas, recubierto de heces, sangre, y orina, el cuerpo en putrefacción de un niño, que conservaba la cabeza dentro de la matriz. El Hach saltando por encima, la anestesió con cloruro de etilo, con el riesgo de dormirnos todos, en la estrecha cueva. Introduje la mano desnuda, hasta el interior de la matriz, metí los dedos en la boca del cadáver, flexionando con fuerza la cabeza, que salió con facilidad. La maniobra había durado pocos minutos. Salí reculando, ante el asombro de la gente, y entregué el niño al padre. Este lo maldijo, lo culpó de los trastornos pasados, y lo arrojó a un cubo agujereado que había por allí. Los vecinos le acompañaron en las maldiciones. 
Volvimos a entrar, la matriz, flácida, no tenía contracciones, no sangraba, pero la placenta permanecía fija y la extracción manual no fue posible, por el riesgo de una hemorragia mortal. Le inyectamos 9 c. c. de penicilina y no tuvimos otra solución que dejar la placenta en el interior del útero. Marchamos con un sentimiento de desagrado y con el convencimiento de que nuestra actuación, no había sido afortunada. Unas semanas después deambulaba tranquila por el zoco.

En otra ocasión un comerciante había comprado sardinas, cinco días antes en Alhucemas, y después de recorrer los zocos del camino, a lomos de un asno, trajo las que no había vendido, al zoco de Beni Ahamed. Llegaron podridas y el veterinario, prohibió su venta, y mandó soterrarlas. Unos sujetos las desenterraron y comieron. Ninguno de ellos tuvo el más mínimo trastorno digestivo.

Los maestros barberos eran escasos y de pocos recursos. Aparte de la operación de fimosis, con muchas infecciones secundarias, practicaban extracciones dentarias, y cauterizaciones, algunas con tan mala fortuna, que a un niño de pocos años, con unas diarreas, le perforaron la pared abdominal.

Una noche de verano, estábamos los miembros de la Intervención tomando el relativo fresco de la noche, cuando el más veterano, comentó que el persistente ruido de un tam-tam que se oía en la lejanía, era causado por una secta llamada Hamadcha, [40] en aquellos momentos fuera de la ley, que ocasionalmente visitaba alguna cabila, pero no sabía con que intenciones, ni de nadie que los hubiera visto. La curiosidad nos estimulaba, y el veterinario y yo, los más jóvenes e inexpertos, decidimos ver lo que hacían. El Interventor y los otros creyeron que la visita podía ser políticamente incorrecta y se abstuvieron, pero nosotros dos, guiados por el sonido del tambor nos dirigimos a una pequeña elevación del terreno que había a unos dos kilómetros. El último tramo del camino ascendía suavemente. Cien metros antes de llegar a la cima, se divisaba el resplandor de una hoguera, que iluminaba las tres o cuatro únicas palmeras, que existían en la cabila, y que movían con pereza y suavidad, las ramas balanceadas por el aura suave y apacible de la noche. El último giro del camino, salía a un pequeño llano que la coronaba. Allí, unos centenares de hombres y mujeres, formaban un corro de cinco o seis hileras 
de personas, sentadas en el suelo. Nos miraron con sorpresa, pero nadie hizo el más pequeño gesto. Nos colocamos en primera fila. En el centro del calvero habían construido una pequeña choza. Tres o cuatro músicos percutían sus atabales y sonaban unas flautas artesanales. El resplandor del fuego iluminaba las caras de los asistentes en un contraste de claridad y sombra. Se repartía te verde que es de suponer contenía una alta proporción de grifa. La luna en cuarto menguante, deformada y amarillenta que asomaba por el horizonte, blanqueaba ligeramente las cumbres de los montes de levante, y el tam tam no paraba. Todo el conjunto formaba un escenario adecuado a la representación que se preparaba.

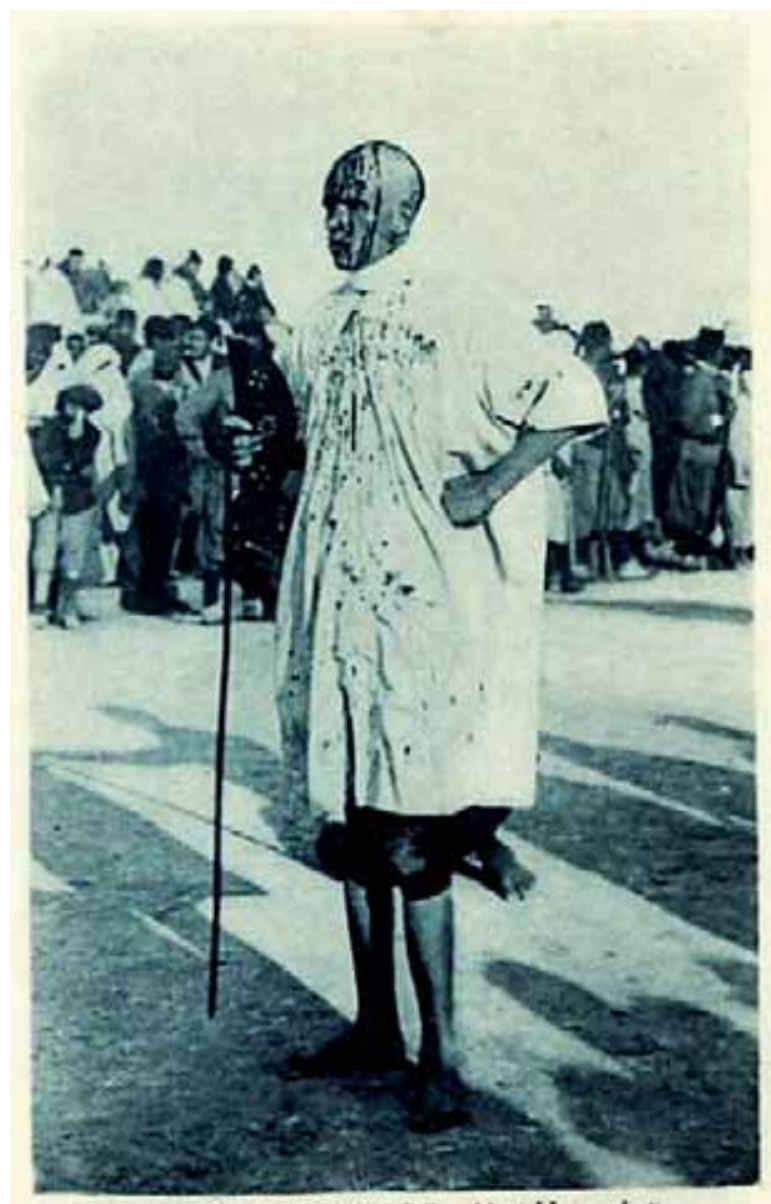

I5 - M.ARRUECOS.-Un "Hamacha"

Fig. 40. Secta hamadcha. 
Uno de los hamduchis, seguía el ritmo del tambor dando saltos verticales con el cuerpo rígido. Periódicamente una mujer del público que llevaba un tiempo con contracciones de espalda, cuello, cara y ojos, saltaba catapultada al espacio central iniciando una danza inconsciente, sincopada y cataléptica, que aumentaba de intensidad, a medida que lo hacía el ritmo del tambor y el chillido estridente de los espectadores. La salida de una bailarina era un estímulo para que saliera otra y otra, la histeria colectiva aumentaba, los tambores seguían acelerando, las danzantes se contorsionaban y daban vueltas sobre si mismas, hasta que agotadas, caían al suelo, donde con el cuerpo arqueado, seguían con contracciones espasmódicas, se mordían la lengua y una espuma sanguinolenta les rezumaba por la comisuras, de los labios. Cuando quedaban agotadas y quietas, en estado cataléptico, las arrastraban por los pies, y las lanzaban entre los asistentes.

Cuando el clímax había alcanzado un alto grado de intensidad, dos hamduschis, sacaron de la choza, dos alabardas como las de los guardas vaticanos, y comenzaron una danza salvaje volteándolas por encima de sus cabezas. Seguidamente, en una pantomima, de movimientos y expresiones muy convincentes, simularon que iban a abrirse la cabeza. Creí que habían enloquecido y me horroricé persuadido de que iban a inmolarse. Uno de los bailarines, dando saltos y revueltas se acercó, y parándose frente a mí, giró con rabia el hacha, que pasó a escasos palmos de mi cuello, es de creer para obtener muestras evidentes de mi pánico. Pero no pude ni pestañear, estaba paralizado por el terror.

Cuando la histeria colectiva llegó al límite, los dos protagonistas con las alabardas, hirieron con dos o tres golpes aparatosos, su cráneo. Con la sangre que salía en abundancia, contorsionándose frotaban su cara, manos y cuerpo. En aquel momento, la locura colectiva alcanzó su máxima expresión. Todos los que querían obtener la salud o asegurarse algún favor, gritando como posesos, corrían empujándose y alargaban la mano para obtener un poco de la sangre milagrosa que brotaba de las heridas de los hamduschis, y con ella se frotaban cara y cuerpo e ingerían golosamente empapada en un pedazo de pan.

El veterinario y yo, permanecíamos sentados en el suelo, como dos estatuas de sal. 
El alboroto se fue calmando, el espectáculo continuaría con períodos de calma en los que solo el tambor dejaba oír su sonido y otros de locura colectiva en los que se repetía la representación presenciada, con nuevos espectadores.

Felipe el veterinario y yo, nos levantamos con esfuerzo y andando a gatas, emprendimos el regreso, en silencio. A medio camino, Felipe dijo: Deberíamos haber marchado antes.Yo contesté: Podías, tu moverte? No, respondió, después de una larga pausa. Anda, vámonos a casa. No volvimos a hablar en todo el camino.

Ketama era una Intervención particular. El Llano Amarillo, Isaguen para los nativos, está a1.500 metros de altura, lo cruza la carretera general Ceuta, Melilla, y el zoco al que se descendía por una pista de $13 \mathrm{Km}$., con curvas cerradas y peligrosas está a 300 metros por debajo del Llano. El invierno es largo y frío, la nieve abundante, y los cedros altos e imponentes abundan en el fondo del valle, donde se celebra el zoco, y reside el personal de la Intervención. Un pequeño canalillo llevaba agua por la superficie a la proximidad de las viviendas, pero no estaba canalizada. El Consultorio y la casa del médico se hallaban apartados, en un pequeño altozano, a unos quinientos metros.

El terreno produce grifa o kifi, en abundancia. La compraban los legionarios, la mehala, y algún comerciante que después la vendía en los puertos de Alhucemas, Ceuta, Melilla y Tánger. Los habitantes de la cabila, la consumían gratuitamente, pero ninguno se enriquecía; su producción excedía a su venta. No pasaban nunca a otras drogas, porqué estas no existían. Los grandes consumidores tenían lo que nosotros llamábamos, el síndrome del camaleón: lentitud de movimientos, habla pausada, siempre flemáticos, tranquilos, pacientes, pero cumplían con su trabajo, y no perdían habilidad, ni fuerza, ni ninguna de las facultades mentales. [41]

En la primavera de aquel año de 1956, comenzaron a visitar las cabilas pequeñas unidades del llamado "Ejército de Liberación” y de representantes del Istiklal, el partido que lideraba sidi Allal el Fasi, que reclutaban adeptos, para sus instituciones. 
Siguieron unos meses en los que imperó un desconcierto total. Las patrullas del Ejército de Liberación recorrían las cabilas, y los españoles, en particular militares, eran mal vistos, surgían altercados, y los caides colaboradores eran perseguidos. España concedió la Interdependencia, a Marruecos, un concepto del que nadie sabía su significado. Francia concedió la Independencia y entonces el desmadre fue general. Evacuaron los Interventores, los militares, las mujeres y los niños, poco después los administradores, auxiliares, maestros, pero a petición del Gobierno marroquí, dejaron a los médicos. Quedamos solos, aislados en medio de una población extraña, sin posibilidad ni de comunicación, ni de transporte, a una distancia infinita de un centro civilizado. [42]

Al retirarse los militares, me entregaron, un fusil y cien cartuchos, para mi defensa. Para gobernar la cabila enviaron un caid de la zona francesa, que no tenía la más pequeña idea de administración, ni de educación, y que nos ignoró completamente.

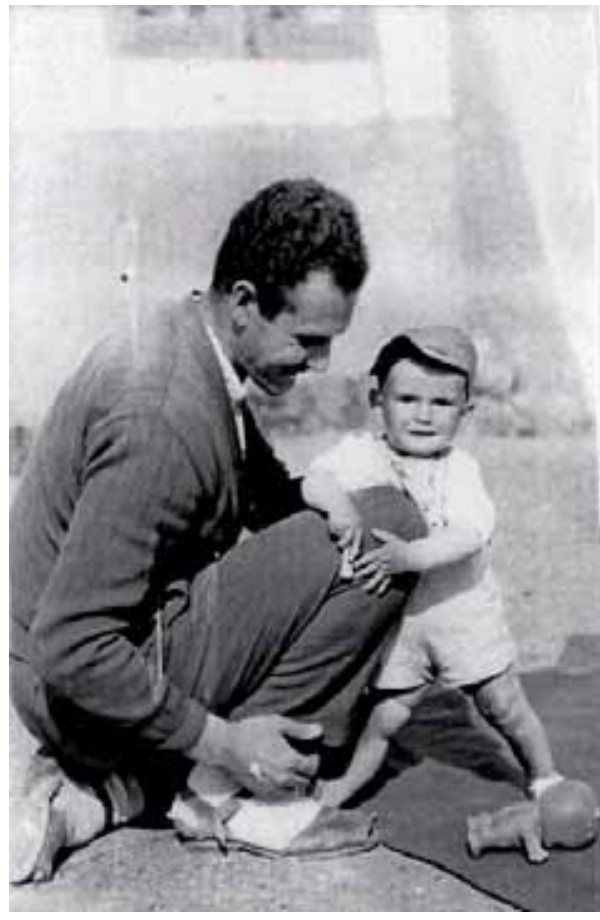

Fig. 41. El doctor Miret con su hijo en el Teleta de Ketama.

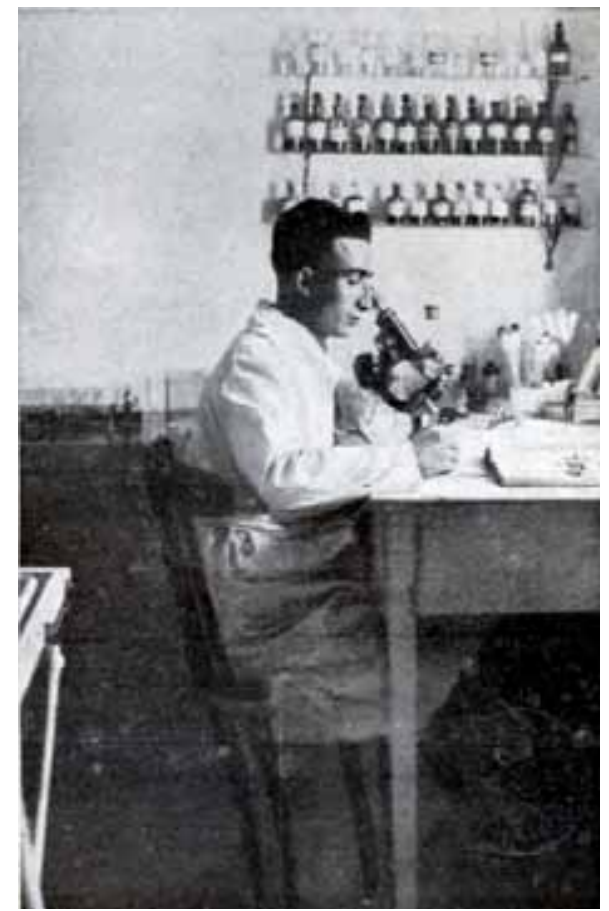

Fig. 42. Doctor español en su laboratorio. 
Las numerosas peripecias de los meses que siguieron, no eran propiamente médicas; tan solo contaremos una, la visita del Ministro de Sanidad, del nuevo Gobierno Marroquí.

El día anunciado, por la mañana, cabalgamos hasta el parador de turismo, que existía en el Llano Amarillo, al lado de la carretera general. La mehasnía, la policía indígena, nos preguntó como debía recibirse un ministro, pero nosotros lo ignorábamos. Ellos se colocaron en la carretera a unos cincuenta metros del parador. Pasó la mañana, llegó la tarde, y al atardecer, cuando los mehasnis estaban tumbados en la cuneta con la sahariana desabrochada, el fusil en el suelo, y el oficial se paseaba hablando solo, vimos acercarse por la parte de Melilla una gran nube de polvo, la carretera no estaba asfaltada, en medio de la cual se vislumbraba un coche que hacia sonar el claxon con insistencia. Los mehasnis se pusieron en pié, el oficial desenvainó el sable, y saltaron hacia atrás cuando el coche pasó rozándoles, a gran velocidad llenándoles de polvo.

Frenó en seco frente el parador, un coche americano de gran cilindrada, y se apeó un sujeto de media edad, robusto que se dirigió a mí, que era el único que le esperaba, gritando: ¿quienes son aquellos locos que se ponen en medio de la carretera para que los atropelle? Aquellos locos llegaban corriendo, sofocados y tosiendo, y se colocaron al lado del ministro con la bayoneta calada, y el oficial con el sable enhiesto. El hombre puso cara de susto, y estoy convencido que creyó que íbamos a secuestrarlo. Por lo que le dije: la guardia que cuida del orden de la cabila, se pone a sus órdenes, y les indiqué que se marcharan rápidamente. Le acompañaba solamente el chofer.

El Dr. Farah que había estudiado la carrera en Paris, donde residió muchos años, hablaba mejor el francés que el árabe. Era muy hablador, y se interesó por nuestro trabajo, por la situación sanitaria y sobretodo por el cultivo del kifi, por su extensión, por su consumo, ganancias...

Cenamos pronto y se acostó. La mañana siguiente, se levantó temprano, ansioso por visitar las plantaciones de grifa, que se encontraban por debajo del Llano Amarillo. Se empeñó en descender con su coche americano y en la primera curva cerrada del camino, con profundos regueros, el vehículo rozó el suelo, se desprendió el cárter y quedó parado a pocos palmos del 
precipicio. Toda la mañana estuvimos recorriendo los plantíos. Por la tarde el hombre estaba eufórico, había encontrado la solución. Cuando yo me haya marchado, dijo, queme todos los campos de grifa, luego ya me cuidaré de encontrar nuevos cultivos.

Para los habitantes de la cabila, los modestos ingresos por su venta, eran los únicos de que disponían, por lo que le dije: yo no la quemaré. Hágalo usted y larguémonos antes de que nos chamusquen, también a nosotros, pero primero le haré una propuesta. Mándeme dos millones de pesetas y compraré toda la grifa que se cultiva en la cabila y después se la mandaré empaquetada a Rabat. Quedó callado. No se quemó, ni se mandaron, ni dos, ni uno, ni parte de los millones solicitados. Años más tarde, el consumo de grifa o marihuana se ha extendió por Europa, y hoy muchos cabileños de Ketama, son hombres ricos y poderosos.

El día siguiente, antes de marcharse, me dijo: súbete al coche, vente comigo a Rabat y te nombraré secretario mío o director del hospital de Casablanca, que en este momento está vacante, lo que prefieras. Era un hombre de resoluciones rápidas. Perdóneme, señor ministro, lo pensaré y se lo comunicaré. Me acordé de mi abuelo Cirilo que me decía: no confíes nunca en personas irreflexivas, siempre saldrás escarmentado.

El Dr. Farach murió, siendo ministro de sanidad, el año 1971, en un atentado contra el rey Hassan II. Mientras celebraban el aniversario del Rey, unos militares con armas automáticas dispararon sobre el monarca, y causaron casi un centenar de muertos. Hassan II resultó ileso. Unos comensales, al entrar los regicidas, se colocaron delante del rey, para protegerlo. Uno de ellos fue el Dr. Farach. Un bel morire tutta una vita onora.

En otoño del año 1957, nos encargaron la dirección del Servicio de Pediatría del Hospital Civil de Tetuán, un pabellón anexo al mismo, construido en el año 1941. En aquellos años, el jefe de Servicio, era el único médico de la unidad. Contaba empero, con un buen equipo; dos monjas, dos enfermeras y cuatro auxiliares. [43]

Cada día una empresa lechera suministraba cien litros de leche que después del control de calidad, se pasteurizaban y se cuajaban, la mitad de ellos, para obtener el suero. 


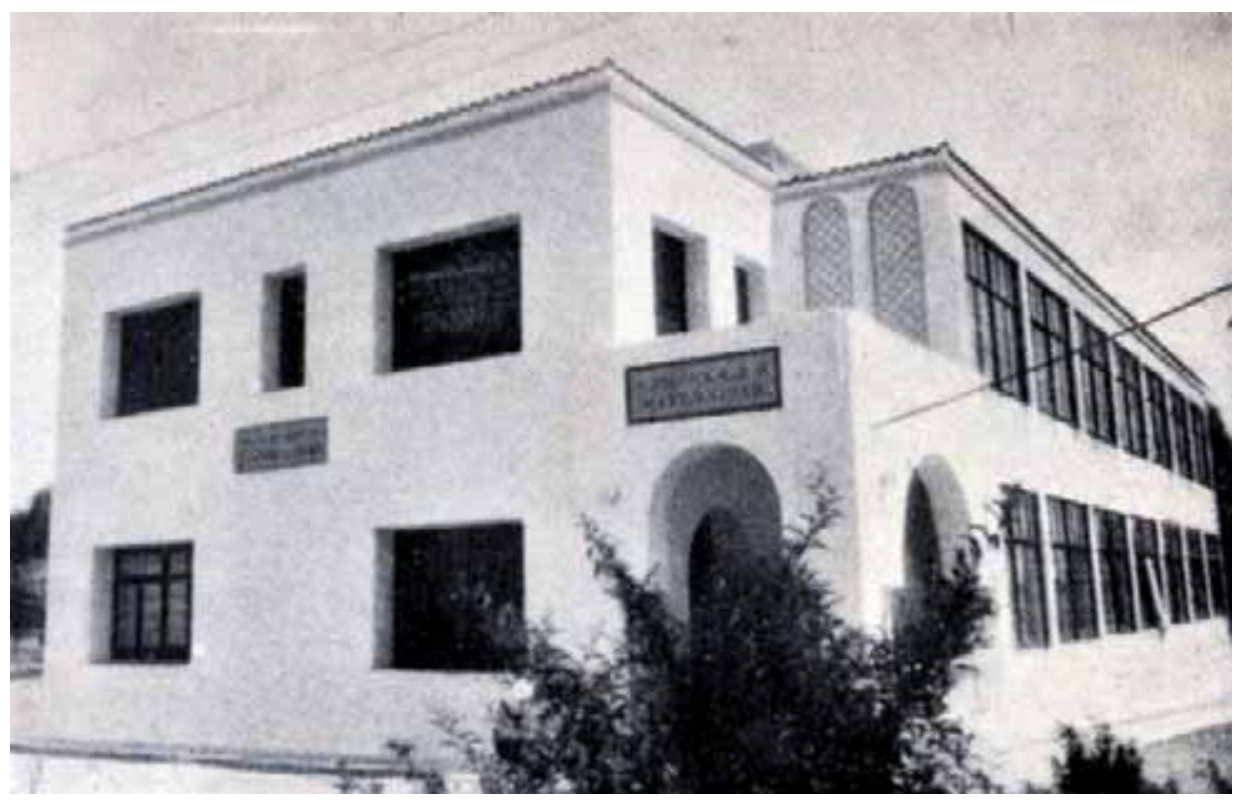

Fig. 43. Pabellón de maternidad en Tetuán.

En la consulta externa se atendía a los niños, desde las nueve de la mañana. Para poner orden en la cola que se formaba en la calle, se destinaban cada día un cabo y un mejasni. Cuando entraban en la sala de consulta, las madres desnudaban completamente a sus hijos y se dirigían a una mesa donde una auxiliar procuraba averiguar si era la primera visita, si era consecutiva, y conservaba la cartilla con la filiación y datos, o si la había perdido, que era lo habitual. Con la cartilla nueva o renovada colocaba el niño desnudo sobre una mesa colocada frente al médico. Ninguno lloraba, todos tenían una patología importante. El interrogatorio muy breve; observabas, estado general, el grado de deshidratación de piel y mucosas, úlceras, infecciones, parásitos, presencia de ganglios, tensión de la fontanela; al mismo tiempo palpabas el abdomen, tamaño del bazo, del hígado, borborigmos, y auscultabas el tórax, crepitantes, subcrepitantes, tonos y ritmo cardíaco. Una de las dos auxiliares, que tenía a ambos lados recogía, en la cartilla, los datos, indicaciones terapéuticas, administración de suero endovenoso o subcutáneo, suero de leche, leche rebajada o entera, curas, penicilina, solicitud de análisis, de radiología, y los mas graves hospitalización. 
La auxiliar la acompañaba a la sala de curas. Allí las enfermeras y monjas aplicaban los tratamientos indicados, procuraban que las madres entendieran las indicaciones, y les entregaban a las que tenían niños deshidratados, botellines de suero de leche, o leche diluida, para el día, y un vale para su entrega en días sucesivos. A las dos se cerraba, la consulta. A continuación, por radioscopia examinábamos a los que tenían problemas respiratorios. Después de un breve refrigerio, se pasaba visita a la sala de hospitalizados, con treinta camas. [44]

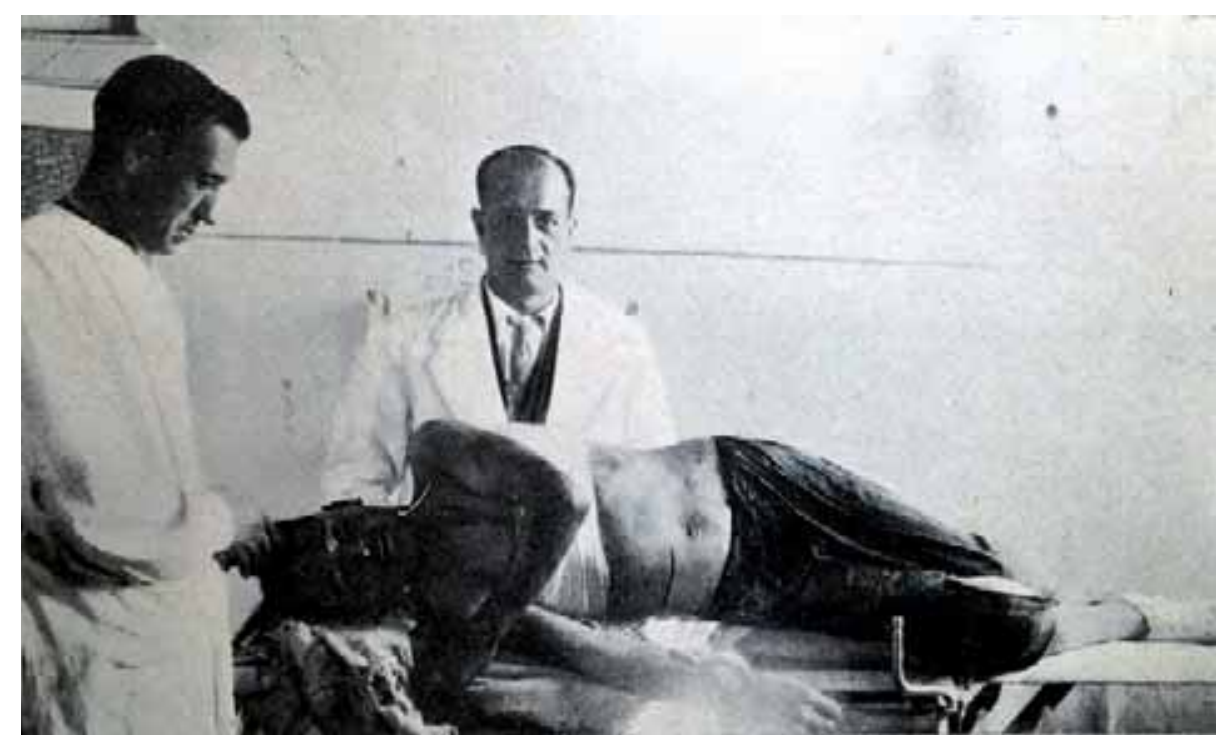

Fig. 44. Atención de pacientes en un centro sanitario.

En el estadillo que firmaba al final no bajaban nunca de doscientos los niños, atendidos, y siempre al terminar, quedaban cincuenta o más personas por atender. Viendo la cara de decepción con la que marchaban, por mi cuenta y riesgo, decidí no terminar la consulta hasta visitar a todos los que esperaban. Seguro que en su interior, hasta las monjas me insultaron, pero nadie protestó, y pasábamos de las trescientas visitas, pero entonces me dí cuenta de la capacidad humana tiene un límite, y que en los últimos visitados se cometían errores graves. Volvimos al horario anterior, para no aumentar los errores propios de la ignorancia, con los que ocasiona el agotamiento de la capacidad intelectual, pero antes de despedir a los que quedaban, se esco- 
gían, de entre ellos, los más graves, para ser atendidos. Para el personal actual, esto es inconcebible.

El mes de diciembre de 1957 estaba en Río Martín substituyendo al médico titular, cuando me avisaron de urgencia, para atender a uno de los dos médicos marroquíes, que existían en la Zona Norte. Lo encontré angustiado, sudoroso, con una mano aferrada al pecho con la pretensión de arrancar el dolor desgarrador que le atormentaba. El diagnóstico era evidente. Sus ojos traslucían un pánico incontrolado a la muerte. Me agarró de un brazo y solo repetía; no me dejes morir, no me dejes morir...

Costó mucho tranquilizarle, solo disponía de nitrito de amilo que no le mejoró porqué la lesión del miocardio era ya irreversible. Envié por morfina a Tetuán, pero llegó al día siguiente. Buscando algún fármaco, de los que disponía, que pudiera ayudarle, me decidí por la teofilina, que nadie ha usado para el infarto de miocardio, pero que puede tener un efecto vasodilatador. Sentado a su lado, le inyecté lentamente teofilina endovenosa. Dos niños menores de diez años, muy asustados, fueron enviados a la cama. La esposa acongojada, atónita y callada, se sentó apartada en un rincón. Él, muy intranquilo, continuaba: no me dejes morir, no me dejes..., le aseguré que sus hijos tendrían padre para muchos años. Por suerte o porqué intervino la Divina Providencia, no se presentaron trastornos del ritmo, ni el temible shock hipovolémico. Por la mañana estaba más tranquilo y el dolor había desaparecido. Al día siguiente de un hospital de la zona francesa enviaron un sujeto que dijo ser cardiólogo, con un aparato portátil de electrocardiografía, una novedad en aquellos años. El hombre no se interesó por el enfermo, solo se preocupó por el registro gráfico, aunque no parecía muy versado en su uso. El artilugio lanzaba chispas, fundía los plomos, silbaba, trepidaba, escupía, menos un trazado entendible, hacía de todo. El Dr. N. N., se enfadó, lo envió de vuelta a la zona francesa y no quiso que lo atendiera nadie más.

Me había limitado a sentarme al lado de la cama y espantar el miedo a morir, de la misma manera que una madre, con un abanico, se sienta en el lecho de un niño con sarampión, para espantar las moscas. [45] 


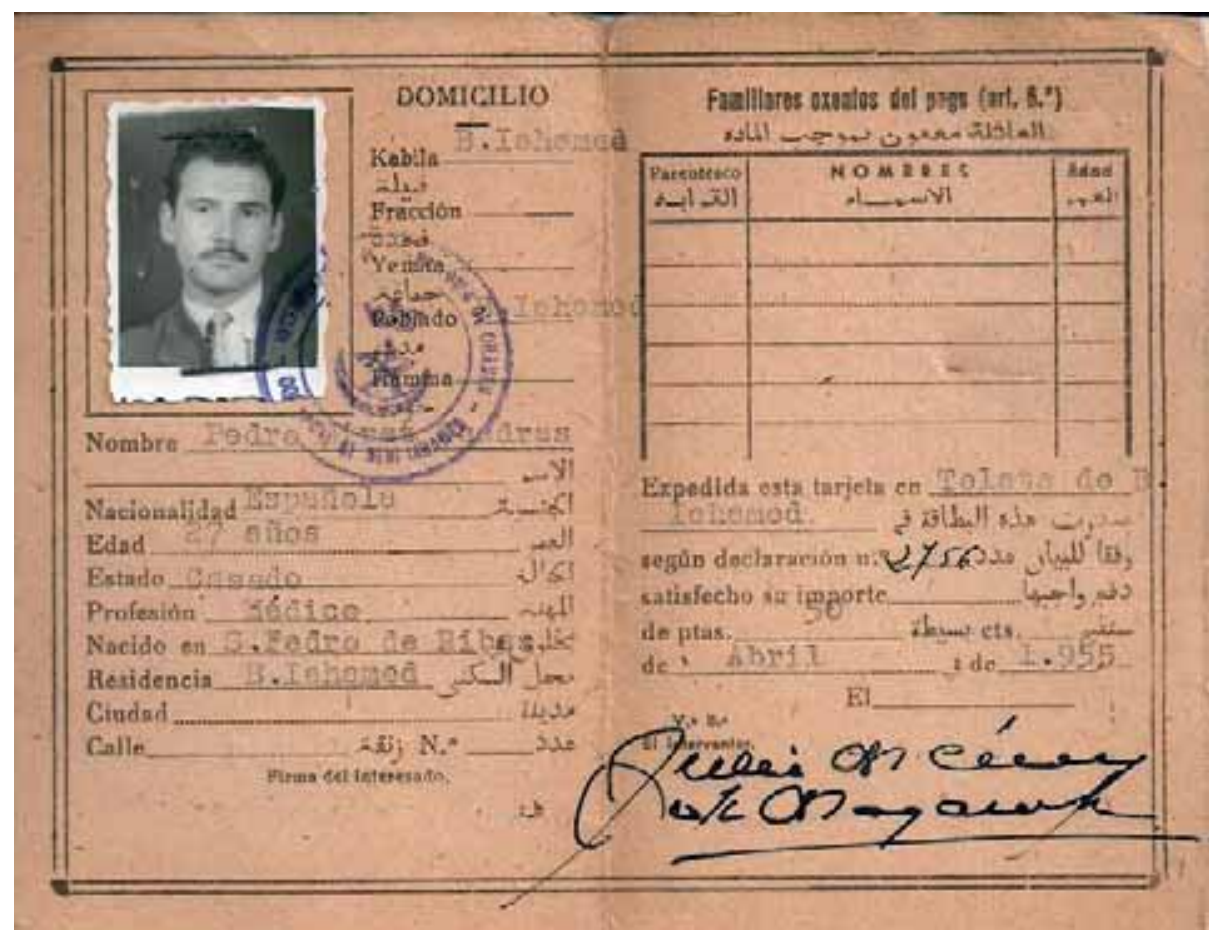

Fig. 45. Carnet del Doctor Miret en el Telata de Beni Ahamed-

\section{Conclusiones}

Organizar un sistema sanitario eficaz y gratuito, en un país pobre, sin ninguna estructura anterior, sin personal médico del país, sin vías de comunicación, sin red eléctrica, con un terreno montañoso y estéril, no apto para la agricultura, no es fácil.

Desde el primer momento la actividad de los médicos militares en las cabilas ocupadas, atendiendo a todos los marroquíes, aunque la intención fuera más política que humanitaria, fue un gran acierto, y por primera vez se trataron correctamente en Marruecos, enfermos de paludismo, sífilis, traumatismos y se vacunó contra la viruela.

Poco a poco se aumentaron los servicios médicos, en las ciudades se construyeron hospitales y se dotaron de nuevos servicios, maternidades, pediatría, oftalmología, odontología. Se creó el Instituto de Higiene, en Tetuán, y 
se abrieron Dispensarios para la Lucha contra la sífilis y el paludismo. Se inauguró el Servicio Farmacéutico, con un depósito en Tetuán y otro en Nador, que abastecían de material y medicamentos gratuitos, a todo el Protectorado. Se construyó un Sanatorio Antituberculoso, en Ben Karrich, y un sanatorio para la lepra, en Larache.

Los resultados fueron muy meritorios. En las ciudades desapareció gradualmente la viruela, el tifus exantemático, la difteria, y disminuyó el kala azar, la disentería, la sífilis, la oftalmia purulenta, el paludismo, la tuberculosis, y la mortalidad en el parto, y en la primera infancia.

El marroquí tenía acceso gratuito a todos los servicios médicos y quirúrgicos, incluida la hospitalización. En las cabilas se instalaron un Consultorio, cercano al zoco de cada Intervención, con un médico, un practicante y una auxiliar.

En Marruecos siete de cada diez habitantes residían en el campo, y el número de nativos de cada cabila, de quince a veinte mil, aunque no todos acudían al centro, no permitía al médico dedicar el tiempo necesario a cada paciente. Era necesario, observar el conjunto, escoger a los que presentaban enfermedades significativas, y contentar de alguna manera a los demás. Era imposible dotar de Centros rurales suficientes, y bien acondicionados, a las cabilas, y mejorar las desfavorables condiciones de la población, del entorno y del terreno. [46]

El nativo sabía que en su territorio podía acudir a un Centro donde curaban enfermos que antes, había visto morir. Unos se convencían de la bondad de las curas, o de la eficacia del tratamiento, volvían, se curaban y conseguían nuevos adeptos, otros más escépticos, interrumpían el tratamiento, cuando mejoraban, y finalmente un último grupo, contrario a la dominación española no pisaba nunca el Consultorio.

Muchos enfermos, residían a tres, cuatro o más horas del Consultorio; si se trataba de un tratamiento para la sífilis, por vía intravenosa, a días alternos, en general, obedecían, ya que la mejoría era espectacular, pero si se trataba de ingerir, pastillas, como es el caso del paludismo, cuando la fiebre desaparecía, abandonaban el tratamiento, recidivaban, cronificaban la enfermedad 
y mantenían la endemia. Buscando una solución, escogimos una persona sensata de cada poblado, la instruimos, y le entregábamos los comprimidos de atebrina plasmoquina (el antipalúdico usado, con buenos resultados) con el compromiso de administrarlos diariamente al enfermo, y los resultados fueron buenos.

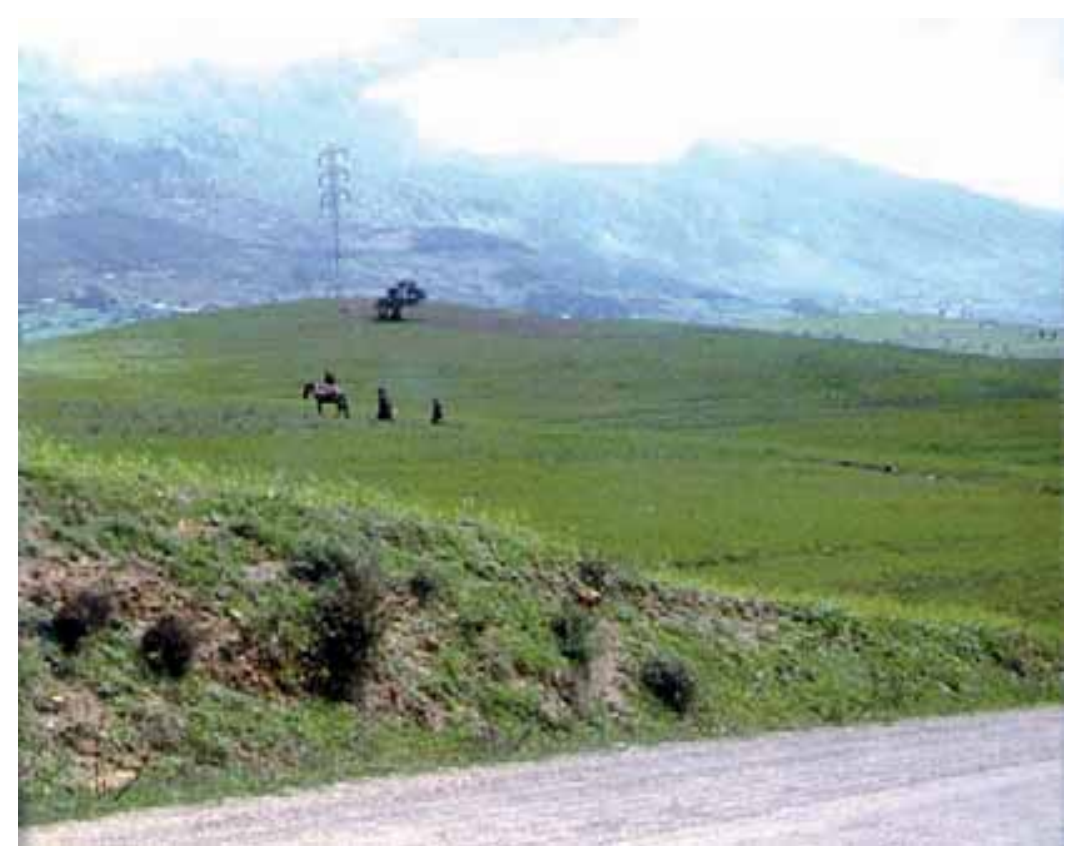

Fig. 46. Paisaje de Beni Hassan.

Dependía única y exclusivamente de la buena voluntad y de la capacidad de un médico, que el enfermo confiara, cumpliera el tratamiento y atrajera nuevos pacientes.

Los traumatizados, y con fracturas, en general no volvían, y los encontrabas en el zoco semanas más tarde, contentos y sonrientes con fragmentos de yeso en forma de anillo que conservaban como un adorno, en el brazo o en la pierna.

Una curiosidad de esta población probablemente debida a la penuria en que vivía, y al instinto de supervivencia, era la extraordinaria tolerancia, y la incomprensible capacidad de recuperación. Además de los casos mencionados, 
de la perforación intestinal y de la mujer a la que dejamos la placenta en el interior de la matriz, otro paciente con luxación completa coxofemoral, desgarro de la cápsula, y del ligamento central, sin más tratamiento que la reducción, muy laboriosa, y el consejo de que descansara durante un mes, deambulaba por el zoco, tres semanas más tarde, y un áscari con una cuchillada desde la rodilla al tobillo, que dejaba al descubierto la tibia, y que atendimos dos días después de la pelea, sin poder cerrar la totalidad de la herida, por la retracción del tegumento, sin ningún antibiótico, epitelizó perfectamente y no se infectó. Y es que la naturaleza humana dispone de recursos ignorados, que emplea solo en casos especiales.

La atención médica en las capitales fue muy meritoria, pero en las cabilas fue incompleta, aunque en aquellos momentos fue la única posible. Todos los marroquíes, tuvieron la oportunidad de conocer una medicina científica, y vieron disminuir, y en algún caso desaparecer, enfermedades que habían diezmado a la población.

La alta mortalidad infantil, la sífilis endémica y el paludismo, que habían disminuido pero no desaparecido, el traslado de enfermos, de la cabilas a los hospitales, el suministro de agua potable, la formación de médicos nativos, el insuficiente número de Centros Médicos rurales, la construcción de vías de comunicación, transitables para vehículos de ruedas, y la falta de Registro Civil, eran los problemas sanitarios más importantes, que quedaban por resolver, en las zonas rurales, al final del Protectorado.

Los médicos de las Intervenciones llevábamos, una vida profesional dura y difícil, pero la compensación fue muy grande. Recibimos mucho, como personas y como médicos. Nos enseñaron la manera de vivir, felices en la pobreza, y sin ninguna de las comodidades que la sociedad considera esenciales, y con muchas de las deficiencias que se consideran inaceptables, nos sentimos útiles y apreciados en aquella colectividad. Tuvimos la ocasión de ver enfermos y enfermedades, de intervenir en actos médicos muy complejos, y de observar actitudes y conductas personales, que nunca en la vida hubiéramos tenido la oportunidad de conocer. Aprendimos mucho de la naturaleza humana, y del hombre enfermo. Nuestro agradecimiento es perenne.

Y a cambio dimos muy poco, seguramente algún ser humano camine 
mejor, haya curado su sífilis o su paludismo, y conservado la vista, o la vida, pero cuando marchamos, el conjunto de la población rural, seguía en el mismo estado de depauperación, de pobreza y de falta de oportunidades para salir de la indigencia, y no tenía ninguna posibilidad de adquirir una cultura.

Es justo agradecer el comportamiento y el sacrificio de las esposas de los funcionarios de las Intervenciones, que padeciendo en mayor grado, las carencias, mantuvieron siempre un espíritu optimista, y fueron las mantenedoras de la buena armonía. [47]

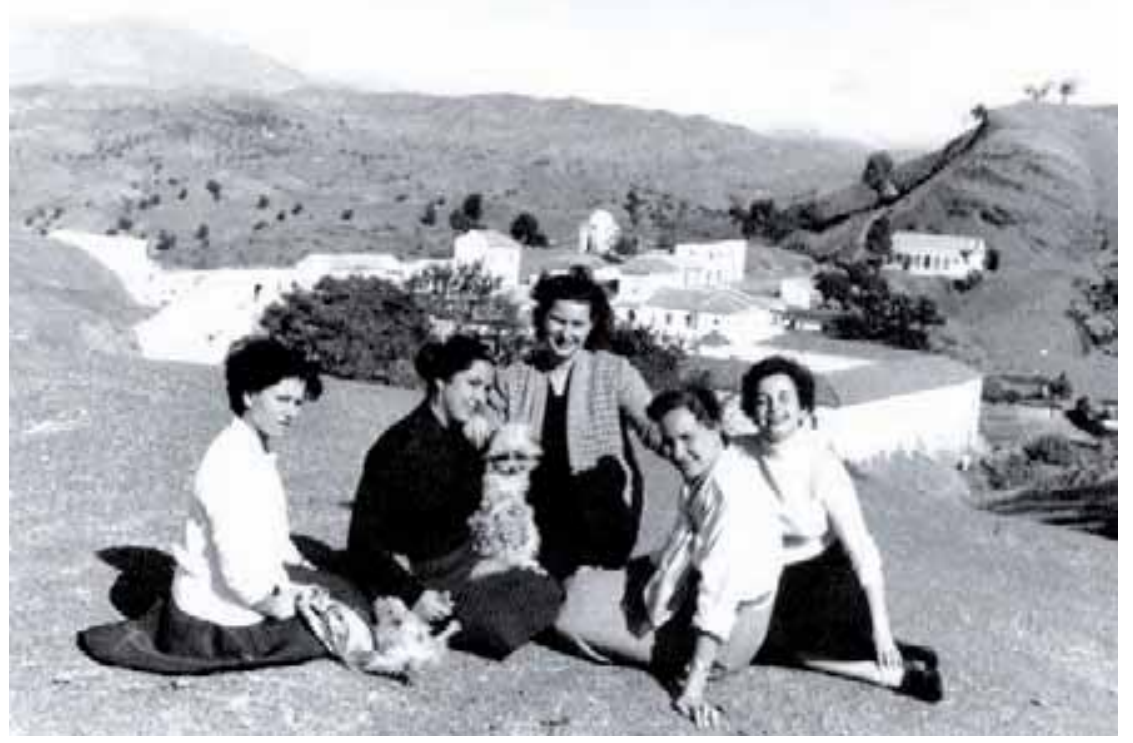

Fig. 47. Personal femenino de la Intervención. Al fondo el zoco y en la lejanía el paisaje desértico de Beni Ahamed.A la derecha, separada, la mezquita sin minarete.

Deseamos que las nuevas generaciones, y su autogobierno hayan superado estas deficiencias, y el pueblo marroquí se halle integrado en una sociedad organizada, culta, justa, fuerte y trabajadora. 


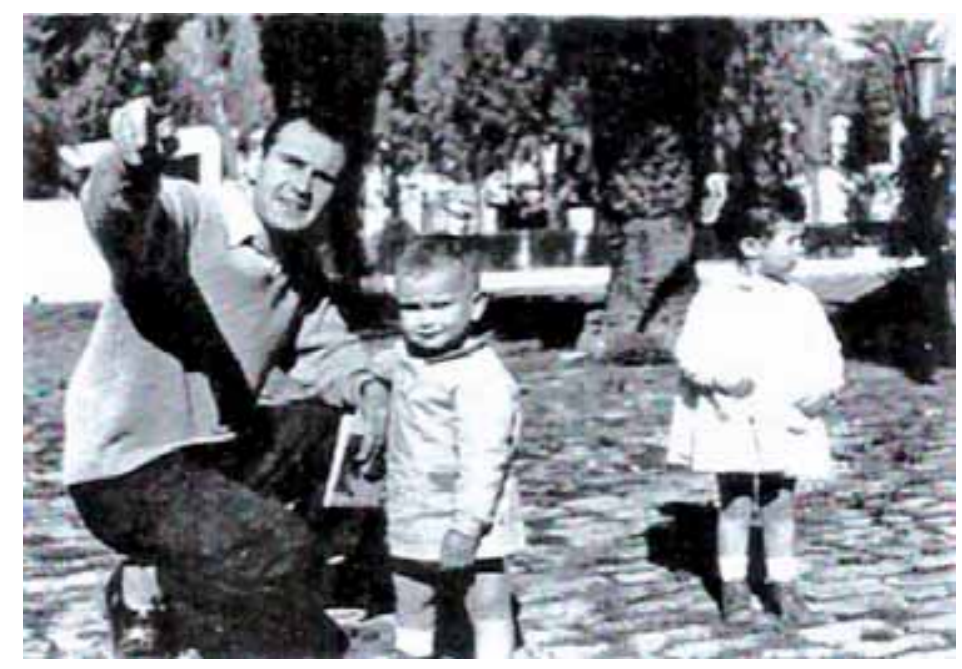

Foto 48. El Doctor Miret con sus hijos en elYemis de Anyera.

\section{Bibliografía $^{2}$}

Cursillo de orientación marroquí, para los nuevos médicos de los Servicios Sanitarios de la Zona (1940). Texto mecanografiado. Biblioteca Nacional, África, Fondo García Figueras, caja 372-15.

GARCÍA FIGUERAS, TOMÁS (1952-1956). Cartas a los Interventores. Texto mecanografiado. Biblioteca Nacional, África, 6.024

Inspección General de Intervención y Fuerzas Jalifianas (1928). Manual para el Oficial del Servicio de Intervención en Marruecos. Madrid, Talleres del Depósito de la Guerra.

Instrucciones provisionales para el servicio que los oficiales médicos deben prestar en los centros de Intervención e Información (1925). Biblioteca Nacional, África, Fondo García Figueras, caja 372-2.

MAESTRE, P. (1923). Divulgación y orientación del problema de Marruecos. Intervención Civil. Intervención Militar. Granada, Imprenta del diario La publicidad. pág. 275.

SOLSONA CUNILLERA, (1962). Del Maestro-Sangrador al Médico. El trabajo y la generosidad de España en la evolución sanitaria de Marruecos. Madrid. Madrid: Fenix.

SOLSONA CUNILLERA, (1939). Breves notas sobre la Organización de los Servicios Sanitarios Oficiales en la Zona de Protectorado Español en Marruecos. Tetuán: Imprenta Hispania.

${ }^{2}$ Queremos manifestar nuestro agradecimiento al profesor Ángel Manuel Hernández Cardona, por sus consejos y revisión del texto, al profesor Eloy Martín Corrales, por la lectura y comentarios del trabajo y al profesor Jacinto Corbella Corbella por la lectura y recomendaciones del contenido. 